\title{
Molecular phylogeny of Parabathynellidae (Crustacea, Bathynellacea), and three new species from Thai caves
}

Ana I. Camacho ${ }^{1,7}$, Paloma Mas-Peinado ${ }^{1}$, Santi Watiroyram ${ }^{2}$, Anton Brancelj ${ }^{3,4}$, Elia Bandari ${ }^{5}$, Beatriz A. Dorda ${ }^{6}$, Adrián Casado ${ }^{6}$, Isabel Rey ${ }^{6}$

${ }^{1}$ Museo Nacional de Ciencias Naturales (CSIC), Dpto. Biodiversidad y Biología Evolutiva, C/ José Gutiérrez Abascal 2, 28006-Madrid, Spain.

${ }^{2}$ Division of Biology, Faculty of Science, Nakhon Phanom University, Nakhon Phanom 48000, Thailand.

${ }^{3}$ National Institute of Biology, Večna pot 111, 1000 Ljubljana, Slovenia.

${ }^{4}$ School for Natural Sciences, University of Nova Gorica, Vipavska c. 13, 5000 Nova Gorica, Slovenia.

${ }^{5}$ Department of Zoology, Government Degree College, Pithapuram 533450, India.

${ }^{6}$ Museo Nacional de Ciencias Naturales (CSIC), Colección de Tejidos y ADN, C/ José Gutiérrez Abascal 2, 28006-Madrid, Spain.

${ }^{7}$ E-mail: mcnac22@mncn.csic.es

Keywords: Biogeography, morphology, molecular phylogeny, Thai cave fauna, Parabathynellidae, 18S, Cox1

\begin{abstract}
A preliminary molecular phylogenetic framework for 12 genera (23 species) of the family Parabathynellidae from Europe, Australia, North Africa and India is presented based on mitochondrial and nuclear markers (Cox1 and 18S). The generated hypothesis places the Southeast Asia genus Paraeobathynella closer to European genera (Iberobathynella, Paraiberobathynella and Parabathynella) than to the Australian (Brevisomabathynella, Atopobathynella, Billibathynella, Octobathynella, Arkaroolabathynella and Lockyerenella) or Indian genera (Habrobathynella), or to the cosmopolitan genus Hexabathynella (Spain and Australia). Three new species of the genus Paraeobathynella from Thailand, P. ratensis n. sp., $P$. siamensis $\mathrm{n}$. sp. and P. hanjavanitiana $\mathrm{n}$. sp., are described based on morphological and molecular features. This is the first record of the genus from Thailand and extends its range of distribution within Asia, where it was previously known only from Vietnam. The new species are clearly separated as independent units at least since the Middle Miocene.
\end{abstract}

\section{Contents}

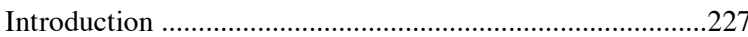

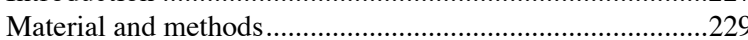

Study area and sampling methods .................................229

Molecular analysis ............................................................231

DNA extraction and PCR amplification ..........................2231

Phylogenetic analyses.......................................................233

Species tree and divergence time estimates .....................233

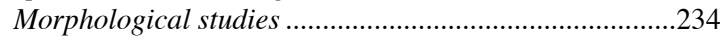

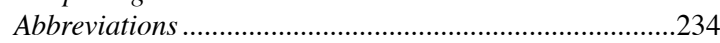

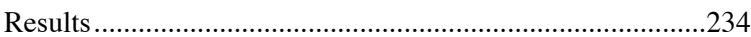

Phylogenetic analyses, species tree and divergence

time estimates .................................................................234

Discussion

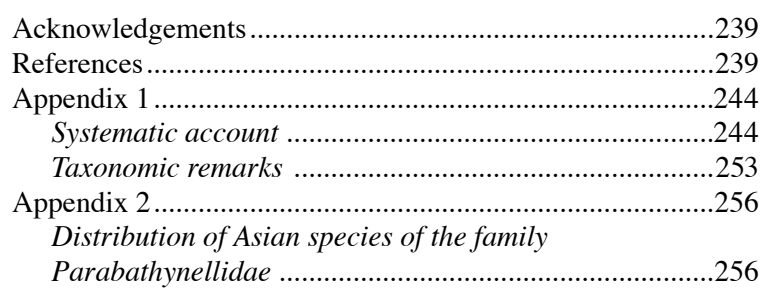

\section{Introduction}

Thailand (Fig. 1) parabathynellids were found in three different locations. These taxa represent three new species of the family Parabathynellidae Noodt, 1965, which is widespread around the world, with 45 genera and 209 species described thus far (Camacho et al., 2017). The family has been poorly studied in Asia, where 17 genera and 74 species occur (see Appendix 2) (Bandari et al., 2016, 2017; Camacho, 2005a; Camacho et al., 2006, 2011; Cho et al., 2008, 2015; Morimoto, 2002; Nam and Cho, 2014; Park and Cho, 2008, 2013, 2015, 2016; Ranga Reddy, 2002, 2004, 2006; Ranga Reddy and Schminke, 2005, 2009; Ranga Reddy et al., 2008, 2014; Ranga Reddy and Totakura, 2010, 2015; Schminke, 1973, 2011; Serban, 1994; Totakura and Reddy, 2014). Two of these genera, Allobathynella Morimoto and Miura, 1957, and Habrobathynella Schminke, 1973, account for half (37) of all the Asian species of parabathynellids known, 23 and 14 species, respectively.

Here we couple molecular sequence data with morphological features to analyze the phylogenetic 


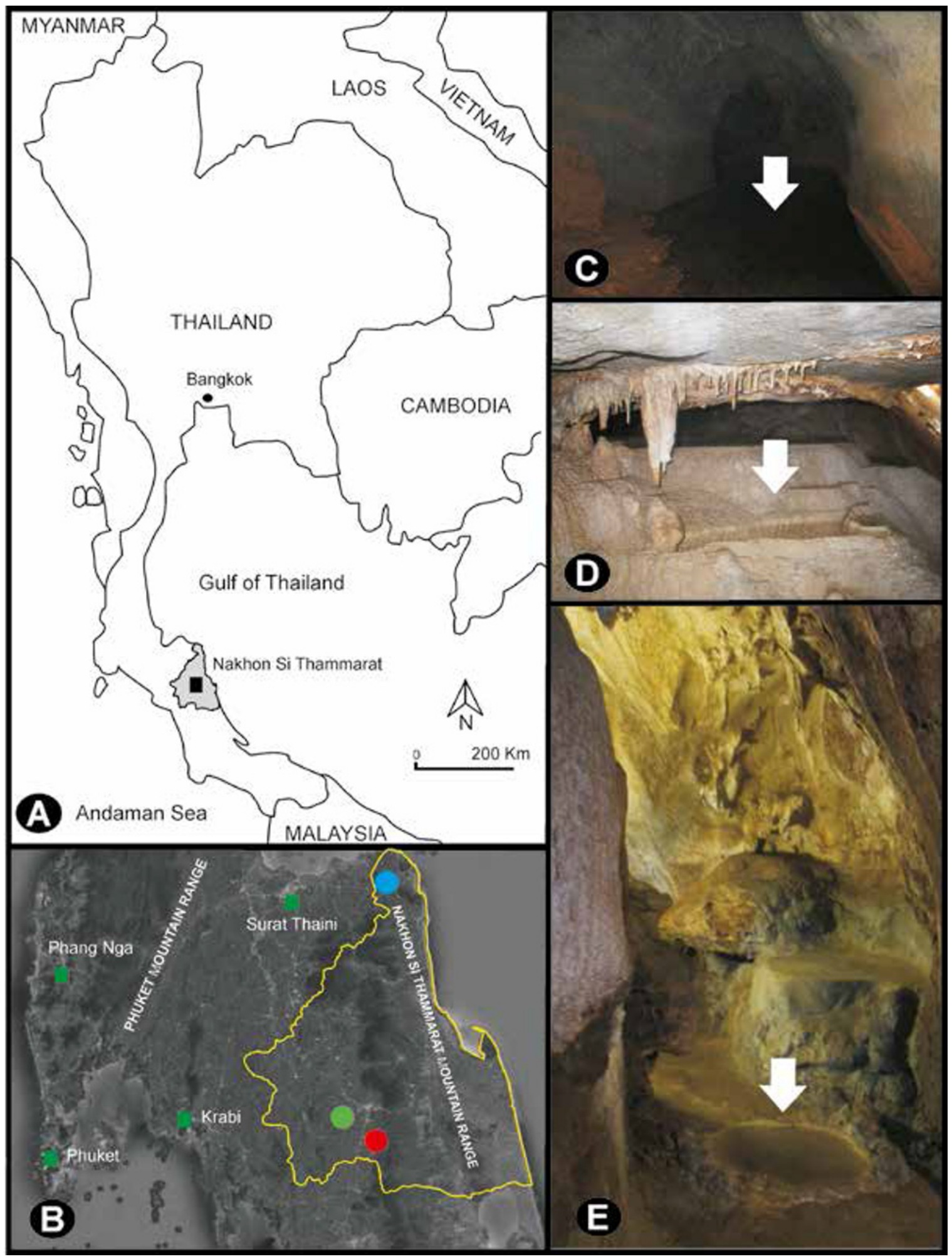

Figure 1. A: Map of the area in Thailand where the three studied caves are located; B: Type localities of the three new species: Khao Krot Cave (blue dot), Rat Cave (green dot), Khao Krot Plu Cave (red dot); C: Habitat of Paraeobathynella siamensis n. sp.; D: Habitat of Paraeobathynella ratensis n. sp.; E: Habitat of Paraeobathynella hanjavanitiana $\mathrm{n} . \mathrm{sp}$. 
relationships among Asian parabathynellids. The only previous study on the relationships among members of this family was based only on morphological features and included only six genera of the so-called "Iberobathynella group" (Camacho et al., 2000). Parabathynellids - and bathynellaceans in general express a high degree of morphological convergence as a result of their common exposure to the same subterranean life conditions. This reflects on the frequent occurrence of species crypticism (Camacho et al., 2012), which complicates even more the resolution of phylogenetic relationships based exclusively on morphological features.

In this study we: (i) describe three new species of the genus Paraeobathynella Camacho, 2005, from Thailand based on morphological and molecular features; (ii) provide a preliminary molecular phylogenetic analysis of the family Parabathynellidae as a framewok to stablish future comparisons; (iii) suggest a paleobiogeographic framework to explain the current distribution of the studied genera; and (iv) update the distribution of the 17 Asian genera of the family Parabathynellidae known to date (Appendix 2).

\section{Material and methods}

\section{Study area and sampling methods}

The specimens used in morphological and genetic analyses were collected in drip water pools at three tourist caves located in the Nakhon Si Thammarat mountain range (Nakhon Si Thammarat Province, southern Thailand; Fig. 1A, B).

Rat Cave (Kapang subdistrict; Thung Song district; $08^{\circ} 02^{\prime} 48.24$ 'N $99^{\circ} 43^{\prime} 42.48^{\prime \prime} \mathrm{E}$; altitude: $89 \mathrm{~m}$ a.s.l.) is a horizontal cave that harbors a chamber about $100 \mathrm{~m}$ high. A sample of about $10 \mathrm{l}$ was collected on 29.10.2015 from a sinter pool located in the dark zone (Fig. 1D).

Khao Krot Plu Cave (Kuanthong subdistrict; Khanom

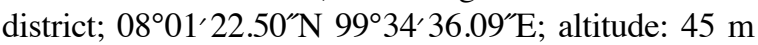
a.s.1.) is a horizontal gallery about $40 \mathrm{~m}$ long. A sample of about 11 was collected on 23.10.2015 from a small concrete pool placed in the dark zone (Fig. 1E).

Khao Plu Cave (Khao Ro subdistrict; Thung Song district;09¹4'22.00”N 9948'72.00”E; altitude: $56 \mathrm{~m}$ a.s.l.) is a horizontal cave about $10 \mathrm{~m}$ long registered as an archaeological site. It is located about $25 \mathrm{~km}$ from Rat Cave. A sample of 201 was collected on 29.10.2015 from a large pool placed in the dark zone (Fig. 1C).
Samples from each location were filtered through a plankton net of $60 \mu \mathrm{m}$ mesh size, transferred into 120 $\mathrm{ml}$ plastic bottles and preserved immediately in the field. All specimens were collected by the $3^{\text {rd }}$ author.

\section{Molecular analysis}

All specimens used in analyses were stored in ethanol 95\% (at $-20^{\circ} \mathrm{C}$ ) (Gilbert et al., 2007). To examine the phylogenetic relationships among taxa, we used partial sequences of the mtDNA gene cytochrome oxidase 1 (Cox 1) (505 bp) and the nuclear 18S rRNA (1372 bp) from a total of 36 specimens ( 23 species in 12 genera). We included 25 specimens of 6 genera of non-Asiatic Parabathynellidae as outgroups (Iberobathynella Schminke, 1973, Paraiberobathynella Camacho and Serban, 1998, Parabathynella Chappuis, 1926, Hexabathynella Schminke, 1972, Habrobathynella and Paraeobathynella) sequenced previously by us, plus GenBank sequences of nine specimens of six Australian genera (Brevisomabathynella Cho, Park and Ranga Reddy, 2006, Billibathynella Cho, 2005, Atopobathynella Schminke, 1973, Octobathynella Camacho and Hancock, 2010, Lockyerenella Camacho and Little, 2016 and Arkaroolabathynella Abrams and King, 2013) and one of the cosmopolitan genus Hexabathynella (also from Australia; Table 2). The species Vejdovskybathynella edelweiss Camacho, 2007, from Spain -a representative of the Parabathynellidae's sister lineage Bathynellidae Grobben, 1905 (Camacho et al., 2017)-, and Anaspides tasmaniae Thomson, 1893, from Tasmania, were chosen as more distant outgroups.

\section{DNA extraction and PCR amplification}

Whole specimens were placed in $0.5 \mathrm{ml}$ digestion buffer (Gilbert et al., 2007), and incubated overnight at $55^{\circ} \mathrm{C}$ with gentle agitation. Buffer consisted of $5 \mathrm{mM}$ $\mathrm{CaCl}_{2}, 2 \%$ sodium dodecyl sulphate (SDS), $40 \mathrm{mM}$ dithiotreitol (DTT), $250 \mathrm{mg} / \mathrm{ml}$ proteinase $\mathrm{K}, 10 \mathrm{mM}$ Tris buffer pH 8, 2.5mM EDTA (Ethylene-DiamineTetra-Acetic acid) $\mathrm{pH} 8.0$, and $10 \mathrm{mM} \mathrm{NaCl}$ (final concentrations). After incubation, nucleic acids were extracted from the digestion buffer using a Qiaquick PCR purification kit (QIAGEN), (Alda et al., 2007).

A 505 base pair (bp) region of the Cox1 gene was amplified with the primers C1-J-1718 (5'-GGAGGATTTGGAAATTGATTAGTTCC-3') and HCO2198 (5'-TAAACTTCAGGGTGACCAAAAAATCA-3') (Folmer et al., 1994; Simon et al., 1994) for all specimens. 
Table 1. Specimens of the three new species of the genus Paraeobathynella Camacho, 2005 with corresponding morphological slides (MNCN/ARTP20.04) and DNA extracts (MNCN/ADN) deposited in the collections of the Museo Nacional de Ciencias Naturales (CSIC) of Madrid, Spain. Number in brackets = number of the specimen from Table 2 used in the molecular analysis.

\section{Species (Number specimen Table 2)}

Paraeobathynella ratensis n. sp.
$(18)$
$(19)$
-----
-----
-----

(20) Holotype

(21)

$-----$

$----$

(22)

(23)

----

$--$

Paraeobathynella siamensis n. sp.

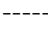

(24)

(25)

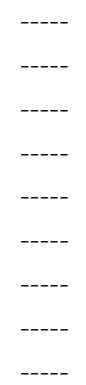

Holotype

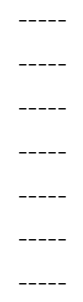

Voucher slides

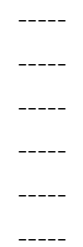

19825 male

19826 male

19827 female

-----

19828 female

19829 male

19830 female

19831 male

19832 male

19833 male

19834 female

19835 female

19836 female
54672

54673

54674

54675

54676

54677

54678

54679

54680

54681

---- 1.58

$\begin{array}{ll}---- & 1.21\end{array}$

$\begin{array}{ll}---- & 1.60\end{array}$

$\begin{array}{ll}---- & 1.72\end{array}$

54682

$54683 \quad 1.49$

54684

$54685 \quad 1.86$

1.29
54686

54687

54688

54689

54690

54691

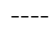

-----

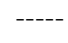

$---$

-----

19837 male

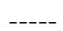

1.84

19838 male

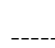

1.69

19839 male

2.35

19840 male

2.60

19841 male

2.02

19842 male

2.24

19843 male

2.62

19844 female

1.84

19845 female

2.40

2.05

1.98

19847 female

1.97

19848 female

2.27

19849 female

2.12 
Table 1 continued

\begin{tabular}{|c|c|c|c|}
\hline Species (Number specimen Table 2) & Voucher slides & Voucher extract & Length $(\mathrm{mr}$ \\
\hline \multicolumn{4}{|l|}{ Paraeobathynella hanjavanitiana $\mathrm{n} . \mathrm{sp}$. } \\
\hline$(26)$ & ----- & 54692 & ----- \\
\hline (27) & ----- & 54693 & ----- \\
\hline$(28)$ & ----- & 54694 & ----- \\
\hline (29) & ----- & 54695 & ----- \\
\hline$(30)$ & ----- & 54696 & ----- \\
\hline$(31)$ & ----- & 54697 & ----- \\
\hline---- & 19851 male & ---- & 1.31 \\
\hline ----- & 19852 male & ---- & 1.72 \\
\hline ----- & 19853 male & ----- & 1.23 \\
\hline ----- & 19854 male & ----- & 1.37 \\
\hline Holotype & 19855 male & ----- & 1.79 \\
\hline ----- & 19856 male & ---- & 1.21 \\
\hline ----- & 19857 male & ---- & 1.37 \\
\hline ----- & 19858 female & ----- & 1.44 \\
\hline ----- & 19859 female & ----- & 1.52 \\
\hline ----- & 19860 female & ----- & 1.51 \\
\hline ----- & 19861 female & ----- & 1.66 \\
\hline ----- & 19862 female & ----- & 1.41 \\
\hline
\end{tabular}

A 1372 bp fragment of the 18S rRNA region was amplified in three fragments, using the primers $1 \mathrm{~F}$ (5'-TACCTGGTTGATCCTGCCAGTAG-3') and 3R (5'-AGGCTCCCTCTCCGGAATCGAAC-3'); 3F (5'-GTTCGATTCCGGAGAGGGA-3') and 5R (5'-CTTGGCAAATGCTTTCGC-3'); and 5F (5'GCGAAAGCATTTGCCAAGAA-3') and 9R (5'GATCCTTCCGCAGGTTCACCTAC-3') (Giribet et al., 1996). Sequences of Australian specimens obtained from GenBank had a shorter 18S rRNA fragment (777 bp). $3 \mu$ l of DNA solution was used as a template. Other components of the $25 \mu \mathrm{l}$ PCR reaction included $1 \mathrm{x}$ of the corresponding buffer $(75 \mathrm{mM}$ Tris $\mathrm{HCl}, \mathrm{pH} 9.0 ; 50$ $\mathrm{mM} \mathrm{KCl}$ and $\left.20 \mathrm{mM}\left(\mathrm{NH}_{4}\right)_{2} \mathrm{SO}_{4}\right), 2 \mathrm{mM} \mathrm{MgCl}, 10$ mM dNTPs mix, $0.1 \mu \mathrm{M}$ of both primers, $0.02 \% \mathrm{BSA}$, and 0.125 units AmpliTaq Gold® DNA Polymerase (Applied Biosystems). The PCR program consisted of an initial denaturation step of $95^{\circ} \mathrm{C}$ for $10 \mathrm{~min}$, followed by 60 amplification cycles $\left(95^{\mathrm{a}} \mathrm{C}\right.$ for $30 \mathrm{~s}, 45^{\circ} \mathrm{C}-49^{\circ} \mathrm{C}$ for $45 \mathrm{~s}$ and $72^{\circ} \mathrm{C}$ for $45 \mathrm{~s}$ ) and a final elongation step of $72^{\circ} \mathrm{C}$ for $10 \mathrm{~min}$. PCR were run on an Eppendorf Mastercycler gradient. $5 \mu \mathrm{l}$ of PCR product were electrophoresed through a $1.5 \%$ agarose gel and visualized with SYBR SafeTM DNA Gel Satin (Invitrogen) under ultraviolet light. PCR products were purified by treatment with
ExoSAP-IT (USB Amersham, Buckinghamshire, UK) and incubated at $37^{\circ} \mathrm{C}$ for $45 \mathrm{~min}$, followed by $80^{\circ} \mathrm{C}$ for $15 \mathrm{~min}$. to inactivate the enzyme. Purified PCR product was then sequenced in both directions using the BigDye Terminator v3.1 sequencing kit (Applied Biosystems Inc., Foster City, USA) in a $10 \mu \mathrm{L}$ volume, containing 15 - $20 \mathrm{ng}$ purified product and 3 pmol primer (Camacho et al., 2015). Sequences obtained were then compared with sequences from GenBank using Blast (Altschul et al., 1997).

DNA was extracted from 26 specimens from Thailand, including 14 specimens from Rat cave (seven whole and the abdomen of seven adults); six whole specimens from Khao Krot Plu cave; and six specimens from Khao Plu cave (see Table 2). All DNA extracts are part of the type series of their respective species, and are deposited in the Tissues and DNA Collection of the Museo Nacional de Ciencias Naturales, Madrid (MNCN) (Table 1). Cox1 and 18S rRNA sequences were obtained from 14 of these specimens (Table 2), and were used together with those of the other 22 specimens (included two outgroups) in the analyses.

Sequences were aligned with MAFFT (Katoh and Toh, 2008) and checked in Mesquite v3.04 (Maddison and Maddison, 2015) to correct the final alignments. All 
Table 2. Specimens used in the molecular analyses. * TL= Type Locality

\begin{tabular}{|c|c|c|c|c|c|c|c|}
\hline \multirow[t]{2}{*}{ Family/Species } & \multirow[t]{2}{*}{ Locality } & \multicolumn{3}{|c|}{ Coordinates } & \multirow{2}{*}{$\begin{array}{l}\text { Voucher } \\
\text { MNCN/ } \\
\text { ADN }\end{array}$} & \multirow{2}{*}{$\begin{array}{l}\text { GB-AN } \\
18 \mathrm{~S}\end{array}$} & \multirow{2}{*}{$\begin{array}{l}\text { GB-AN } \\
\text { Cox1 }\end{array}$} \\
\hline & & $\mathrm{N}$ & $\mathrm{E}$ & $\mathrm{Z}(\mathrm{m}$, asl $)$ & & & \\
\hline \multicolumn{8}{|c|}{ PARABATHYNELLIDAE Noodt, 1965} \\
\hline $\begin{array}{l}\text { 1. Iberobathynella imuniensis } \\
\text { Camacho, } 1987\end{array}$ & $\begin{array}{l}\text { *Torca Morteros Cave, } \\
\text { Burgos, Spain }\end{array}$ & 43.14786 & -3.59539 & 1285 & 29166 & KC469528 & HQ659850 \\
\hline $\begin{array}{l}\text { 2. Iberobathynella ortizi } \\
\text { Camacho, } 1989\end{array}$ & $\begin{array}{l}\text { *Rei Cintolo Cave, Lugo, } \\
\text { Spain }\end{array}$ & 43.39364 & -7.36786 & 409 & 54616 & MF436209 & MF443322 \\
\hline $\begin{array}{l}\text { 3. Iberobathynella } \\
\text { parasturiensis Camacho \& } \\
\text { Serban, } 1998\end{array}$ & $\begin{array}{l}\text { *CO. } 209 \text { Cave, Cantabria, } \\
\text { Spain }\end{array}$ & 43.26725 & -4.59085 & 1132 & 29556 & КC999699 & КC974001 \\
\hline $\begin{array}{l}\text { 4. Iberobathynella cornejoensis } \\
\text { Camacho, } 2005\end{array}$ & $\begin{array}{l}\text { *Redonda Cave, Burgos, } \\
\text { Spain }\end{array}$ & 43.03236 & -3.62913 & 668 & 29946 & KP999701 & KP974108 \\
\hline $\begin{array}{l}\text { 5. Iberobathynella burgalensis } \\
\text { Camacho, } 2005\end{array}$ & $\begin{array}{l}\text { *Ojo Guareña Cave (OG09), } \\
\text { Burgos, Spain }\end{array}$ & 43.03188 & -3.65821 & 724 & 29520 & HQ659859 & KC469529 \\
\hline $\begin{array}{l}\text { 6. Iberobathynella celiana } \\
\text { Camacho, } 2003\end{array}$ & Viar stream, Sevilla, Spain. & 37.71374 & -5.87772 & 60 & 29452 & HQ659862 & KC469527 \\
\hline $\begin{array}{l}\text { 7. Paraiberobathynella cf fagei } \\
\text { (Delamare Deboutteville \& } \\
\text { Angelier, 1950) }\end{array}$ & Pileta Cave, Málaga, Spain & 36.69133 & -5.26981 & 729 & 54581 & KC999742 & КР974043 \\
\hline $\begin{array}{l}\text { 8. Paraiberobathynella } \\
\text { maghrebensis (Boutin \& } \\
\text { Coineau, 1987) }\end{array}$ & $\begin{array}{l}\text { well, Nador, Maghreb, } \\
\text { Morocco }\end{array}$ & 34.95238 & -2.59795 & 276 & 29935 & KC469532 & KC469542 \\
\hline 9. Parabathynella $\mathrm{sp}$ & Poltarica spring, Slovenia & 45.88681 & 14.7684 & 272 & 54669 & MF436211 & MF443326 \\
\hline $\begin{array}{l}\text { 10. Hexabathynella sevillaensis } \\
\text { Camacho, } 2005\end{array}$ & $\begin{array}{l}\text { *Santiago Grande Cave, } \\
\text { Sevilla, Spain }\end{array}$ & 38.03013 & -5.90429 & 358 & 29545 & KC469526 & HQ659869 \\
\hline 11. Hexabathynella $\mathrm{sp} 1$ & $\begin{array}{l}\text { *Port Kenny, South } \\
\text { Australia, Australia }\end{array}$ & -33.1564 & 134.6445 & ------ & ----- & JQ446049 & JN817387 \\
\hline $\begin{array}{l}\text { 12. Brevisomabathynella cooperi } \\
\text { Cho, Park \& Ranga Reddy, } \\
2006\end{array}$ & $\begin{array}{l}\text { Jundee, West Australia, } \\
\text { Australia }\end{array}$ & -26.2827 & 120.6757 & ------ & ------ & JQ446065 & EU350254 \\
\hline $\begin{array}{l}\text { 13. Brevisomabathynella } \\
\text { uramurdahensis Cho \& } \\
\text { Humphreys, } 2010\end{array}$ & $\begin{array}{l}\text { Bubble well, West Australia, } \\
\text { Australia }\end{array}$ & -26.56073 & 120.0408 & ------ & ------ & JQ446073 & JN817407 \\
\hline 14. Billibathynella $\mathrm{sp} .2$ & $\begin{array}{l}\text { Moorarie, West Australia, } \\
\text { Australia }\end{array}$ & -27.41337 & 117.7112 & ------ & ----- & JQ446059 & JN817401 \\
\hline $\begin{array}{l}\text { 15. Atopobathynella hinzeae } \\
\text { Cho, Humphreys \& Lee, } \\
2006\end{array}$ & $\begin{array}{l}\text { Depot spring, West } \\
\text { Australia, Australia }\end{array}$ & -27.93010 & 120.0584 & ------ & ----- & JQ446051 & JN817391 \\
\hline $\begin{array}{l}\text { 16. Atopobathynella } \\
\text { glenayleensis Cho, } \\
\text { Humphreys \& Lee, } 2006\end{array}$ & $\begin{array}{l}\text { Carnegie Downs, West } \\
\text { Australia, Australia }\end{array}$ & -25.6685 & 122.3686 & ------ & ------ & JQ446052 & EU350256 \\
\hline $\begin{array}{l}\text { 17. Octobathynella peelensis } \\
\text { Camacho \& Hancock, } 2010\end{array}$ & $\begin{array}{l}\text { *Peel river, New South } \\
\text { Wales, Australia }\end{array}$ & -30.9561 & 150.8017 & ------ & ----- & JQ446076 & JQ446076 \\
\hline $\begin{array}{l}\text { 18. Paraeobathynella ratensis } \\
\text { n. sp. }\end{array}$ & $\begin{array}{l}\text { *Rat Cave, Thung Song } \\
\text { (Kapang), Thailand }\end{array}$ & 8.04672 & 99.72847 & 89 & 54673 & MG321597 & MG271865 \\
\hline $\begin{array}{l}\text { 19. Paraeobathynella ratensis } \\
\text { n. sp. }\end{array}$ & $\begin{array}{l}\text { *Rat Cave, Thung Song } \\
\text { (Kapang), Thailand }\end{array}$ & 8.04672 & 99.72847 & 89 & 54674 & MG321598 & MG271866 \\
\hline $\begin{array}{l}\text { 20. Paraeobathynella ratensis } \\
\text { n. sp. }\end{array}$ & $\begin{array}{l}\text { *Rat Cave, Thung Song } \\
\text { (Kapang), Thailand }\end{array}$ & 8.04672 & 99.72847 & 89 & 54678 & MG321599 & MG271867 \\
\hline $\begin{array}{l}\text { 21. Paraeobathynella ratensis } \\
\text { n. sp. }\end{array}$ & $\begin{array}{l}\text { *Rat Cave, Thung Song } \\
\text { (Kapang), Thailand }\end{array}$ & 8.04672 & 99.72847 & 89 & 54680 & MG321600 & MG271868 \\
\hline $\begin{array}{l}\text { 22. Paraeobathynella ratensis } \\
\text { n. sp. }\end{array}$ & $\begin{array}{l}\text { *Rat Cave, Thung Song } \\
\text { (Kapang), Thailand }\end{array}$ & 8.04672 & 99.72847 & 89 & 54682 & MG321601 & MG271869 \\
\hline $\begin{array}{l}\text { 23. Paraeobathynella ratensis } \\
\text { n. sp. }\end{array}$ & $\begin{array}{l}\text { *Rat Cave, Thung Song } \\
\text { (Kapang), Thailand }\end{array}$ & 8.04672 & 99.72847 & 89 & 54684 & MG321602 & MG271870 \\
\hline $\begin{array}{l}\text { 24. Paraeobathynella siamensis } \\
\text { n. sp. }\end{array}$ & $\begin{array}{l}\text { *Khao Krot Plu Cave, } \\
\text { Khanom (Kuanthong), } \\
\text { Thailand }\end{array}$ & 9.23944 & 99.82000 & 56 & 54687 & MG321603 & MG271871 \\
\hline
\end{tabular}


Table 2 continued

\begin{tabular}{|c|c|c|c|c|c|c|c|}
\hline \multirow[t]{2}{*}{ Family/Species } & \multirow[t]{2}{*}{ Locality } & \multicolumn{3}{|c|}{ Coordinates } & \multirow{2}{*}{$\begin{array}{l}\text { Voucher } \\
\text { MNCN/ } \\
\text { ADN }\end{array}$} & \multirow{2}{*}{$\begin{array}{l}\text { GB-AN } \\
18 \mathrm{~S}\end{array}$} & \multirow{2}{*}{$\begin{array}{l}\text { GB-AN } \\
\text { Cox } 1\end{array}$} \\
\hline & & $\mathrm{N}$ & $\mathrm{E}$ & $\mathrm{Z}(\mathrm{m}$, asl $)$ & & & \\
\hline $\begin{array}{l}\text { 25. Paraeobathynella siamensis } \\
\mathrm{n} . \mathrm{sp} \text {. }\end{array}$ & $\begin{array}{l}\text { * Khao Krot Plu Cave, } \\
\text { Khanom (Kuanthong), } \\
\text { Thailand }\end{array}$ & 9.23944 & 99.82000 & 56 & 54688 & MG321604 & MG271872 \\
\hline $\begin{array}{l}\text { 26. Paraeobathynella } \\
\text { hanjavanitiana } \mathrm{n} . \mathrm{sp} \text {. }\end{array}$ & $\begin{array}{l}\text { *Khao Plu Cave, Thung } \\
\text { Song (Khao Ro), Thailand }\end{array}$ & 9.02292 & 99.57669 & 45 & 54692 & MG321605 & MG271873 \\
\hline $\begin{array}{l}\text { 27. Paraeobathynella } \\
\text { hanjavanitiana } \mathrm{n} . \mathrm{sp} \text {. }\end{array}$ & $\begin{array}{l}\text { *Khao Plu Cave, Thung } \\
\text { Song (Khao Ro), Thailand }\end{array}$ & 9.02292 & 99.57669 & 45 & 54693 & MG321606 & MG271874 \\
\hline $\begin{array}{l}\text { 28. Paraeobathynella } \\
\text { hanjavanitiana } \mathrm{n} . \mathrm{sp} \text {. }\end{array}$ & $\begin{array}{l}\text { *Khao Plu Cave, Thung } \\
\text { Song (Khao Ro), Thailand }\end{array}$ & 9.02292 & 99.57669 & 45 & 54694 & MG321607 & MG271875 \\
\hline $\begin{array}{l}\text { 29. Paraeobathynella } \\
\text { hanjavanitiana } \mathrm{n} . \mathrm{sp} \text {. }\end{array}$ & $\begin{array}{l}\text { *Khao Plu Cave, Thung } \\
\text { Song (Khao Ro), Thailand }\end{array}$ & 9.02292 & 99.57669 & 45 & 54695 & MG321608 & MG271876 \\
\hline $\begin{array}{l}\text { 30. Paraeobathynella } \\
\text { hanjavanitiana } \mathrm{n} . \mathrm{sp} \text {. }\end{array}$ & $\begin{array}{l}\text { *Khao Plu Cave, Thung } \\
\text { Song (Khao Ro), Thailand }\end{array}$ & 9.02292 & 99.57669 & 45 & 54696 & MG321609 & MG271877 \\
\hline $\begin{array}{l}\text { 31. Paraeobathynella } \\
\text { hanjavanitiana } \mathrm{n} . \mathrm{sp} \text {. }\end{array}$ & $\begin{array}{l}\text { *Khao Plu Cave, Thung } \\
\text { Song (Khao Ro), Thailand }\end{array}$ & 9.02292 & 99.57669 & 45 & 54697 & MG321610 & MG271878 \\
\hline $\begin{array}{l}\text { 32. Habrobathynella schminkei } \\
\text { Ranga Reddy, } 2004\end{array}$ & $\begin{array}{l}\text { Godavari river, Devipatnam, } \\
\text { South India }\end{array}$ & 17.31428 & 81.68090 & ----- & 54764 & MF436210 & MF443325 \\
\hline $\begin{array}{l}\text { 33. Lockyerenella danschmidti } \\
\text { Camacho \& Little, } 2017\end{array}$ & *Queensland, Australia & -27.54144 & 152.3936 & ------ & ------ & KX022524 & KX022565 \\
\hline $\begin{array}{l}\text { 34. Arkaroolabathynella robusta } \\
\text { Abrams \& King, } 2013\end{array}$ & $\begin{array}{l}\text { *Yaltipena spring, South } \\
\text { Australia, Australia }\end{array}$ & -31.21939 & 138.7430 & ----- & ------ & JQ898528 & JQ898526 \\
\hline \multicolumn{8}{|l|}{ BATHYNELLIDAE Grobben, 1905} \\
\hline $\begin{array}{l}\text { 35. Vejdovskybathynella } \\
\text { edelweiss Camacho, } 2007 \\
\text { OUTGROUP }\end{array}$ & $\begin{array}{l}\text { *Ojo Guareña Cave (OG01), } \\
\text { Burgos, Spain }\end{array}$ & 43.03188 & -3.65821 & 724 & 29478 & KP999677 & HQ596565 \\
\hline \multicolumn{8}{|l|}{ ANASPIDIDAE Thomson, 1893} \\
\hline $\begin{array}{l}\text { 36. Anaspides tasmaniae } \\
\text { (Thomson, 1893) } \\
\text { OUTGROUP }\end{array}$ & $\begin{array}{l}\text { Mount Wellington, } \\
\text { Tasmania, Australia }\end{array}$ & ------ & ------- & ----- & ----- & L81948 & AF048821 \\
\hline
\end{tabular}

sequences used in analyses were submitted to GenBank (see Tab. 2 for locality, collection voucher number and GenBank Accession Number for each specimen). We calculated the nucleotide substitution model for both genes using the Bayesian Information Criterion (BIC) and the Akaike Information Criterion (AIC) (Posada and Buckley, 2004) implemented in JModelTest v2. (Darriba et al., 2012).

\section{Phylogenetic analyses}

Were carried out using Maximum Likelihood (ML) and Bayesian Inference (BI) methods. Maximum Likelihood analysis was implemented in RAxML (Stamatakis et al., 2014) using 10.000 bootstrap replicates to assess node support. Bayesian Inference analysis was run in MrBayes v.3.2.2 (Ronquist et al., 2012). We explored the substitution model space with the option lset nst=mixed rates=invgamma. We ran different analyses with the partition scheme suggested in PartitionFinder (Lanfear et al., 2012, 2014) for $100 \times 10^{6}$ generations, discarding the first $25 \%$ generations as burnin, and synthesizing the resulting trees in a $50 \%$ majority rule consensus tree. The consensus phylogenetic tree was then edited in FigTree v.1.4.2. (http://tree.bio.ed.ac.uk/software/figtree).

\section{Species tree and divergence time estimates}

A multilocus species tree analysis of Thailand populations was carried out using the concatenated matrix $(\mathrm{Cox} 1+18 \mathrm{~S})$ and the multispecies coalescent method *BEAST implemented in BEAST v.1.8.4 (Drummond et al., 2012). Base on the results of ML and BI analyses together with the morphological data we incorporated as a priori information the three predefined groups (Thai species). In addition, we estimated divergence times between lineages 
following a Bayesian-coalescence approach as implemented in BEAST 1.8.4. The analysis relies on the use of relaxed molecular clocks to reconstruct the genealogy of the samples under study together with different demographic and temporal parameters. To calibrate the molecular clock we used the substitution rates estimated for insects in Papadopoulou et al., (2010), with a prior on the substitution rates of the mitochondrial genes ranging from $1.5 \%$ my-1 to 2.3 $\%$ my-1, and from $0.05 \%$ my-1 to $0.1 \%$ my- 1 for the nuclear genes. We specified as a speciation tree prior a Birth-Death Incomplete Sampling (Stadler, 2009), and examined the trace plots and Effective Sample Size (ESS) value in Tracer v.1.5 to evaluate the convergence of the Markov Chain Monte Carlo (MCMC). The results were summarized and annotated in a maximum clade credibility tree (MCC) generated in TreeAnnotator (Drummond et al., 2012), removing previously the first $25 \%$ of the topologies as burnin.

\section{Morphological studies}

Twelve specimens of the Rat Cave population (Paraeobathynella ratensis $\mathrm{n}$. sp.; six females and six males); 14 specimens from Khao Krot Plu Cave ( $P$. siamensis $\mathrm{n}$. sp.; seven females and seven males); and 12 specimens from Khao Plu Cave (P. hanjavanitiana n. sp.; five females and seven males) were used for morphological study (see Table 1 for specimen vouchers).

These specimens constitute the morphological type series of the three new species described herein. A complete dissection of all appendages in all specimens was done and the resultant parts preserved as permanent slides (special metal slides, glycerinegelatine stained with methylene blue and paraffin as mounting medium; see Perina and Camacho, 2016). Morphological examination was performed using an oil immersion lens (at 1000x magnification) with a Zeiss interference microscope equipped with a drawing tube. Photographs were taken with a Leica camera (LEICA MC170 HD) attached to the microscope with 400X magnification. These photographs cannot replace the drawings in which all the planes are integrated offering the overall image, but allow observation of details in a realistic way. The material is deposited in the Collection of Arthropoda of the Museo Nacional de Ciencias Naturales (MNCN), Madrid (Spain).

The terminology used throughout the text follows Serban (Serban, 1972, 1980, 1985; Serban and Coineau, 1975, 1982, 1990, 1994; Coineau and Serban, 1978).

\section{Abbreviations}

Morphology. AI: antennule; AII: antenna; End: endopod; Exp: exopod; Md: mandible; Mx.I: maxillule; Mx.II: maxilla; sgt : segment; Th I-VIII: Thoracopods I-VIII; Symp: Sympod; Urp: uropod. Distribution. Ha: Habitat; TL: Type Locality.

Acronyms. MNCN: Museo Nacional de Ciencias Naturales de Madrid (Spain); CSIC: Consejo Superior de Investigaciones Científicas (Spain); ARTP: Arthropods collection of the MNCN; MNCN/ADN: Tissues and DNA collection of the MNCN; GB-AN: Genbank accession number.

\section{Results}

Phylogenetic analyses, species tree and divergence time estimates

The concatenated data set for the Cox 1 and $18 \mathrm{~S}$ consisted of 1182 bp derived from 36 sequences. PartitionFinder recognized four partitions under the BIC criterion, three separate codon positions for the Cox 1 fragment and a separate partition for the whole $18 \mathrm{~S}$ fragment $(\mathrm{p} 1=1-505 \backslash 3 ; \mathrm{p} 2=2-503 \backslash 3 ; \mathrm{p} 3=3-504 \backslash 3$ and $\mathrm{p} 4=506-1882)$. The details of the nucleotide substitution model identified by JModelTest are Cox1 $\mathrm{TVM}+\mathrm{I}+\mathrm{G}$ and $18 \mathrm{~S} \mathrm{GTR}+\mathrm{I}+\mathrm{G}$ according to the Akaike Information Criterion (AIC); and Cox $1 \mathrm{GTR}+\mathrm{I}+\mathrm{G}$ and $18 \mathrm{~S}$ TrNef $+\mathrm{I}+\mathrm{G}$ according to the Bayesian Information Criterion (BIC).

The phylogenetic analyses under Maximum Likelihood (ML) (bootstrap support, BS) and Bayesian Inference (BI) (posterior probabilities, PP) yielded identical topologies (Fig. 2). Based on these analyses, the Parabathynellidae appear as a monophyletic family $(\mathrm{PP}=1 \mathrm{BS}=84)$ composed of four well-supported major clades. One clade, A (Fig . 2) $(\mathrm{PP}=1 \mathrm{BS}=100)$ includes the three new species of the genus Paraeobathynella from Thailand. P. siamensis n. sp. $(\mathrm{PP}=1 \mathrm{BS}=100)$, located in the north of the Nakhon Si Thammarat province (Khao Krot cave), is sister to the other two species from the south region: $P$. ratensis n. sp. (Rat cave) and $P$. hanjavanitiana n. sp. (Khao Plu cave). The second sister clade (B) according to Bayesian analyses $(\mathrm{PP}=0.96)$ includes the European and North African genera Iberobathynella, Paraiberobathynella and Parabathynella ( $\mathrm{PP}=1 \mathrm{BS}=99)$. Parabathynella from Slovenia was recovered as the sister genus $(\mathrm{PP}=1$ $\mathrm{BS}=94$ ) to the taxa from the Iberian Peninsula and 


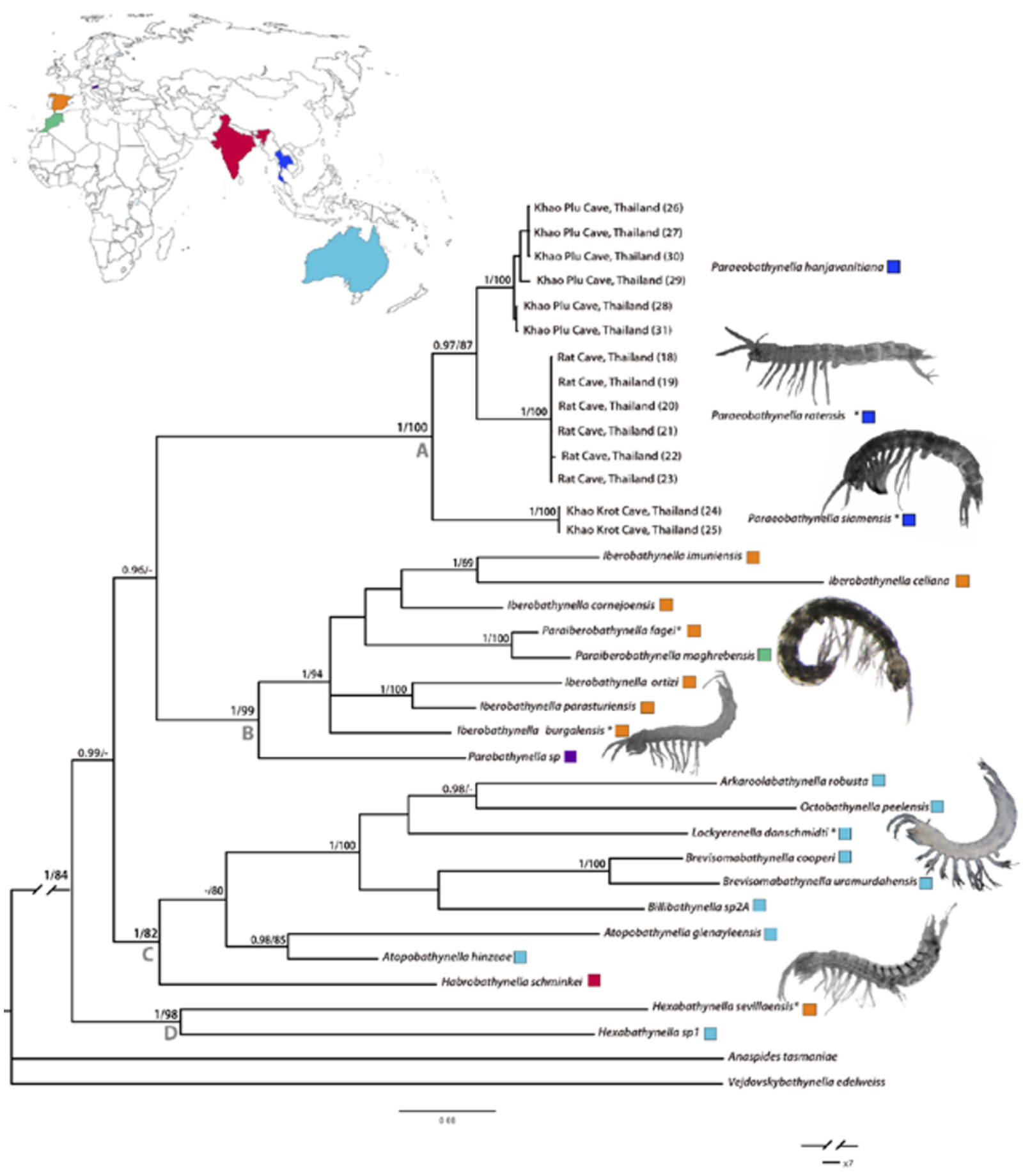

Figure 2. Phylogenetic relationships within the family Parabathynellidae. Bayesian phylogenetic tree based on $1882 \mathrm{bp}$ of mtDNA and nDNA sequences (Cox1 and 18S). The same topology was recovered under a Maximum Likelihood approach. Support for each node is represented by the Posterior probabilities (PP) resulting from the Bayesian Inference analysis and the Bootstrap support values (BS) obtained for the Maximum Likelihood tree (PP/BS). Colored squares encode distribution of their respective taxa in adjacent map. Species remarked with asterisk appear represented in respective adjacent photos. The numbers in brackets correspond to the number of Thai specimens that appear in Table 2. 


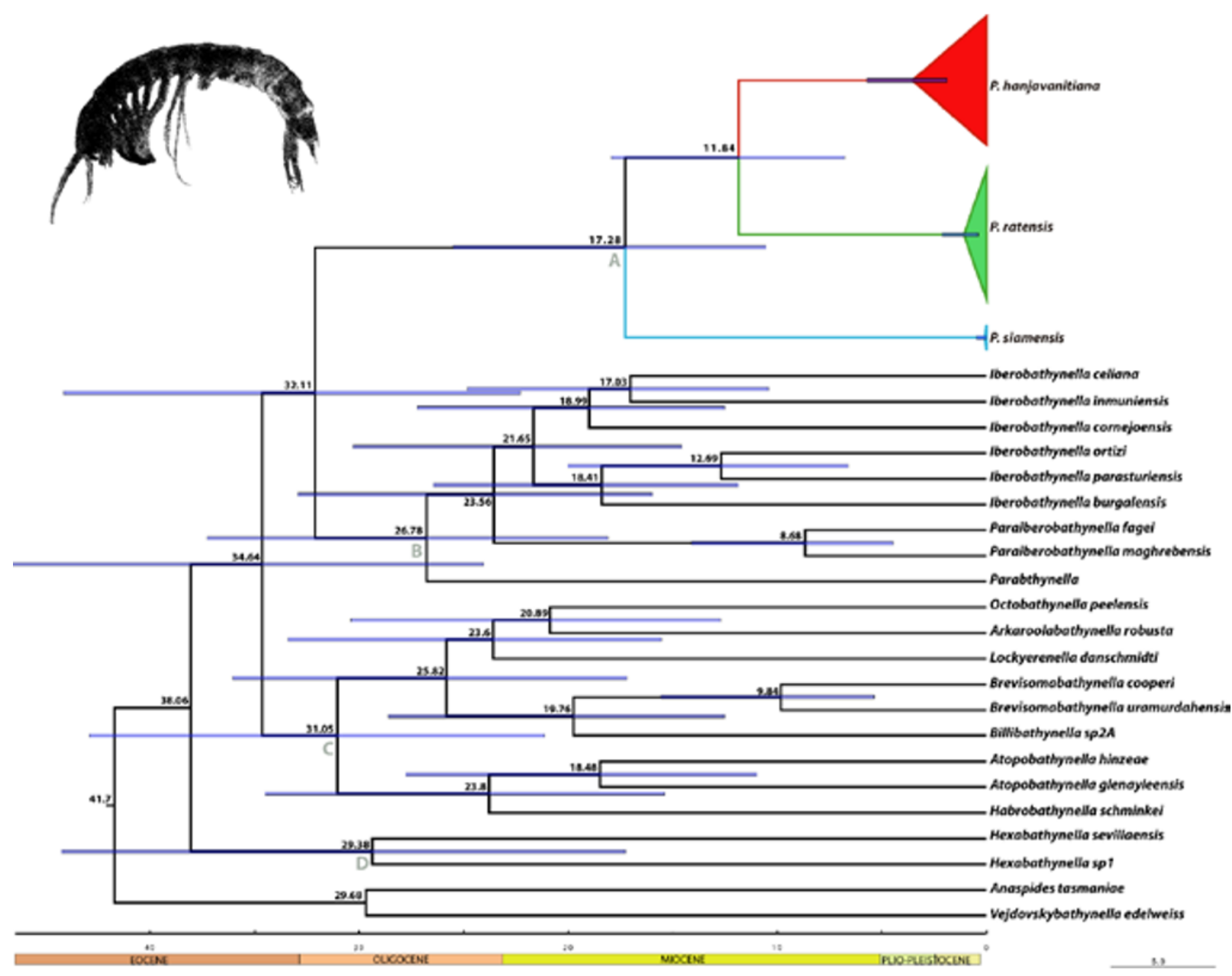

Figure 3. Temporal estimates derived from a relaxed molecular clock analysis. Divergence times are depicted in the coalescence-based MCC tree. Blue bars at nodes indicate $95 \%$ highest posterior density (HPD) intervals, and X-axis reflect Mya. The three new species of Thailand are colored in red (Paraeobathynella hanjavantiana n. sp.), green (P. ratensis $\mathrm{n} . \mathrm{sp}$.$) and blue (P. siamensis \mathrm{n}$. sp.).

Morocco (Fig. 2). The third clade, $\mathrm{C}(\mathrm{PP}=1 \mathrm{BS}=82)$ comprises the Australian genera Brevisomabathynella, Atopobathynella, Billibathynella, Octobathynella, Arkaroolabathynella, Lockyerenella $(\mathrm{BS}=80)$ and the Indian genus Habrobathynella. The fourth clade, D $(\mathrm{PP}=1 \mathrm{BS}=98)$, recovered as sister to the other three, includes the cosmopolitan genus Hexabathynella from the Iberian Peninsula and Australia.

In the time divergence analyses, we obtained the highest ESS (Effective Sample Size) values (over 400), specifying a lognormal relaxed clock with the substitution rates priors for each gene Cox $1=1.8 \%$ my-1 (Mean 0.009) and 18S=0.08\% (Mean 0.0005).

As a firt time divergence framework for the family Parabathynellidae, in general our result showed broad intervals of High Probability Density at basal nodes. The recovered time for the most recent common ancestor (TMRCA) of the Parabathynellidae fell during Eocene, 38.1 Mya (95\% HPD: 25.98-51.8) (Fig. 3). The TMRCA for the Paraeobathynella from Thailand suggests a Late Miocene diversification, at 17.28 Mya (95\% High Probability Density: 10.52-25.51). The split between the species $P$. hanjavanitiana $\mathrm{n}$. sp. and $P$. ratensis $\mathrm{n}$. sp. took place during the Tortonian, at 11.84 Mya (95\% HPD: 6.7917.94) (Fig. 3).

The analysis of the species tree based on Cox 1 and $18 \mathrm{~S}$ genes using *BEAST, recovered with a strong support $(\mathrm{PP}=1)$ the specimens from the three populations of Thailand as different species (Fig. 
4A). Mitochondrial DNA (Cox1) and nuclear (18S) haplotypes networks of Thailand lineages support these three different species and recover the higher haplotypic diversity within Khao Plu cave (Fig. 4B).

\section{Discussion}

The discovery of the genus Paraeobathynella in Thailand, previously known only from Vietnam, reflects the paucity of knowledge of the diversity of the groundwater fauna of Asia. Only South Korea, India and Japan have been relatively well sampled for parabathynellids, with 28, 20 and 11 species known, respectively. Allobathynella, Eobathynella and Nipponbathynella Schminke, 1973, present in Japan and South Korea, account for half of the known species
(36) in the region (74). Many Asian genera are very similar in morphology and some of their diagnoses are incomplete and/or share many presumed diagnostic traits, resulting in a questionable generic assignment of many species. For example, the provisional diagnosis by Schminke (2011) of Allobathynella is also applicable to Paraeobathynella, Eobathynella, Sketinella. Unfortunately, there are no Cox1 or $18 \mathrm{~S}$ sequences available for Asian genera such as Allobathynella, Eobathynella, Kampucheabathynella or Sketinella, or for the type species of the genus Paraeobathynella ( $P$. vietnamensis), to assess how close are all these taxa to the the three new species described herein. These three new species differ significantly in terms of morphological (Appendix 1) and molecular features, and are easily identified based on these traits (Clade A; Fig. 2). They share with the type species of the genus

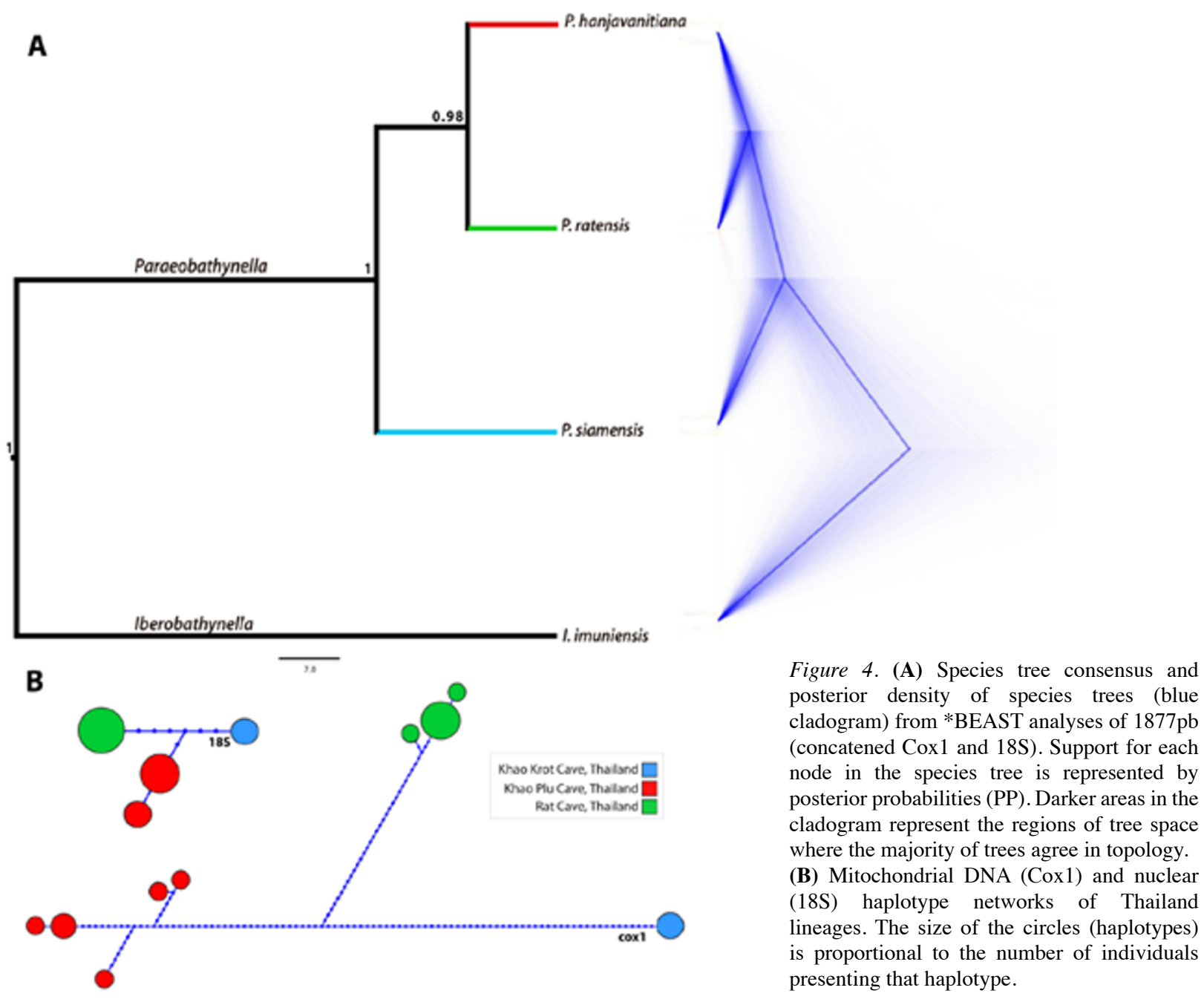


the common display of a crest on the basipod of male Th VIII with a distinctive shape, which unites them in the genus Paraeobathynella. But each one displays a unique combination of characters on their own, especially with regard to dimensions and appearance of both the outer lobe and the basipod of the male Th VIII (Appendix 1). Other more subtle differences between them pertain to the length of both setae and teeth present on mouthparts, the density of secondary setation, and the relative proportions of thoracopodal segments, antennae and uropods. All these features are certainly subjective and can sometimes be deformed by fixation and mounting of the animals. It is therefore essential to perform molecular analyses to complement the species diagnoses, and the partial sequences of cytochrome oxidase I (Cox 1$)$ and $18 \mathrm{~S}$ of the three new species obtained herein complement their traditional morphological taxonomic description .

Our phylogeny demonstrates the existence of at least three highly divergent clades in the Parabathynellidae, corresponding to (i) the European and North African genera (Iberobathynella, Paraiberobathynella and Parabathynella) (B in Fig. 2) plus the three new Asian species (A in Fig. 2); (ii) the Australian genera together with Habrobathynella (Asian genus) (C in Fig. 2); and (iii) the cosmopolitan genus Hexabathynella (D in Fig. 2). The three new species from Thailand undoubtedly belong to the same genus. Paraeobathynella siamensis n. sp. is the sister species to the other two new species (Figs 2, 3), which agrees with the results of the morphological study. Furthermore, our study recovers Parabathynella from Slovenia as sister to Iberobathynella and Paraiberobathynella, two genera from the Iberian Peninsula and Morocco. Paraiberobathynella was created by Camacho and Serban (1998) to accommodate the "fagei" (Delamare Deboutteville and Angelier, 1950) and the "maghrebensis" (Boutin and Coineau, 1987) species-groups of Iberobathynella because they were morphologically different from the rest of the species in the genus. These subdivisions should be reconsidered now since our molecular data do not support the retention of Paraiberobathynella as a distinct genus.

The analysis shows also that the eight Australian species form a monophyletic group that includes also a species from India. It is interesting to remark also that the two species included in the analysis of the cosmopolitan genus Hexabathynella, from places as distant as Spain and Australia, meet in a clade that is sister to the rest of the clades obtained.

Bathynellaceans are obligate groundwater inhabitants and are distributed worldwide. On a large scale, the distribution of both fossil and recent syncarids seems to respond to a biogeographic model of double vicariance (Boutin and Coineau, 1990; Coineau and Boutin, 1992) triggered by plate tectonics and periods of positive marine eustatism (Coineau and Camacho, 2013). Syncarida were already diversified in the Paleozoic (Schram, 1977; Camacho and Coineau, 1989; Coineau and Camacho, 2013), and constituted an important element of the crustacean communities present in brackish and freshwater environments on the margins of Laurentia during the Carboniferous (Andrew 2005; Camacho and Valdecasas, 2008). Brooks (1962) writes that Bathynellacea are probably descendents of the archaic ancestors of all Syncarida and Serban (1972) pointed out that Bathynellacea has a "bathynelloïde" structure that differentiate them from Malacostraca and Syncarida, separating them into a higher group Podophallocarida; Schram and Hof (1998) found Bathynellacea sorting separately from Anaspidacea as an ancestor of the Malacostraca (including the Anaspidacea). Camacho et al., 2002 summarized the result of Brooks, Serban and Schram and Hof and renewed the old controversies on the systematic position of Bathynellacea within Malacostraca with the first molecular data. It may be that Serban's (1972) proposal of a new superorder "Podophallocarida" for the Bathynellacea, outside the Syncarida, is worth reconsidering. With this argument it could be that the origin of Podophallocarida/Bathynellacea was pre-Pangaea. They could have spread across Pangea, including a substantial Gondwanan colonization from which the taxa currently found in Australia and Brazil were derived (Schram, 1981, 1984). This occupation of Gondwana took place in the Permian-Triassic (250200 Mya), before the break-up of Pangea (175 Mya) (Golonka and Gaweda, 2012; Coineau and Camacho, 2013; Hutchison, 2014).

The fragmentation of Pangea (150 Mya) in the Mesozoic (Golonka, 2007) led to the current disjunct distribution of syncarids (Schram, 1977) and Bathynellacea, and induced their independent evolution on each landmass. Thus, the break-up of eastern Gondwana separated Madagascar from northwestern Australia in the mid-Cretaceous (90 Mya) (Gibbons et al., 2012). India began to move away from Australia about 130 Mya in the Early Cretaceous, and from Madagascar about 90 Mya (Late Cretaceous) (Raval and Veeraswamy, 2003). This scenario would explain the occurrence of Habrobathynella in India and Madagascar and its closer kinship to the Australian 
genera rather than to other Asian genera (Fig. 2, 3). All genera of Parabathynellidae present in peninsular India show also a Gondwanan heritage (Ranga Reddy, 2011; Bandari et al., 2016). The same holds for genera of Bathynellacea such as Atopobathynella (from Chile, Australia, Tasmania, New Zealand and India); Parvulobathynella Schminke, 1973 (Chile, Paraguay, Brazil, South Africa and India); and Chilibathynella Noodt, 1973 (Chile, Australia and India). All these genera probably originated before the break-up of southern Gondwana.

The genera comprising the monophyletic Iberobathynella-group (Camacho, 2003), are found in the Iberian Peninsula, USA (Texas and California) and the Maghreb (Morocco, Algeria). This group is distributed across three continents with a presumed origin in Laurentia. Continental drift subdivided the area in Early Triassic times (245 to 205 Mya; Golonka, 2007), when the separation of the Iberian Peninsula and North America started (Yilmaz et al., 1996) and parts of Portugal, Galicia and Salamanca, as well as California and Texas, had already emerged (Yilmaz et al., 1996). The Iberian Peninsula separated from Africa 100 Mya. ago, resulting in the oldest divergences in the Iberobathynella-group (Camacho et al., 2000). Paraiberobathynella must have had an ancestor that lived early on the Tethys seashore and so, as suggested by the present distribution, it was able to colonize emerged land before Senonian times (88.5 to $65 \mathrm{Mya}$ ) when the island Mallorca, the Iberian Peninsula and the Alboran plate were in the same land mass (Yilmaz et al., 1996; Camacho et al., 2000).

The genus Hexabathynella is known from several continents: Europe, North America, South America, South Africa, Madagascar, Australia and New Zealand (Schminke, 1972a, 1973; Camacho, 1986, 2005b; Cho, 2001, 2006; Cho and Schminke, 2006). Such a world-wide disjunct distribution is most probably a result of the fragmentation of Pangea (Golonka, 2007) which was inhabited by the common ancestor of those species (Coineau and Camacho, 2013). Our results showed Hexabathynella from Spain and Australia formed a well-supported, monophyletic group which is clearly differenciated from the rest of genera studied. According to our divergence time estimates, the split between the Thailand clade and the European-North African clade took place not later than the Middle Eocene (Fig. 3).

Ouranalyses suggestanEarly Miocenediversification (Burdigalian Stage) for the most recent common ancestors (TMRCA) of Paraeobathynella in Thailand.
The split between the species P. hanjavanitiana n. sp. and $P$. ratensis n. sp. took place during the Tortonian Stage probably resulting from local geologic events.

\section{Acknowledgements}

We gratefully acknowledge C. Puch who has helped us in different ways. Thanks also to Damián Jaume who has provided us with specimens of three species for molecular analysis. Thanks to Arabia Sánchez for the help in the producing of microscope photographs. We thank the reviewers Damián Jaume, Fred Schram, Nicole Coineau, and one anonymous person for their constructive comments. This work was supported by CGL201566571-P, MINECO/FEDER project and the National Research Council of Thailand (Grant No. 2559A13402007).

\section{References}

Abrams K, Rachael AC, King A, Michelle AB, Guzik MT, Steven A, Cooper SJB, Austin AD. 2013. Molecular phylogenetic, morphological and biogeographic evidence for a new genus of parabathynellid crustaceans (Syncarida: Bathynellacea) from groundwater in an ancient southern Australian landscape. Invertebrate Systematics 27: 146-172.

Alda F, Rey I, Doadrio I. 2007. An improved method of extracting degraded DNA samples from birds and other species. Ardeola 54: 331-334.

Altschul SF, Madden TL, Schäffer AA, Zhang J, Zhang Z, Miller W, Lipman DJ. 1997. Gapped blast and psi-blast: a new generation of protein database search programs. Nucleic Acids Research 25: 3389-3402.

Andrew J. 2005. Biogeography and systematics of the Tasmanian mountain shrimps of the family Anaspididae (Crustacea: Syncarida) (Doctoral dissertation, University of Tasmania).

Bandari E, Shaik S, Ranga Reddy Y. 2016. Two new species of the genus Habrobathynella Schminke, 1973 (Syncarida, Parabathynellidae) from the southwestern peninsular India. Zootaxa 4150(2): 149-167.

Bandari E, Shaik S, Ranga Reddy Y. 2017. A phylogenetic review of the genus Atopobathynella Schminke, 1973 (Crustacea, Malacostraca, Bathynellacea) with three new species from southeastern India. Journal of Natural History doi.org/10.1080/00222933.2017.1360528

Birstein JA, Ljovuschkin SI. 1964. Occurence of Bathynellacea (Crustacea, Syncarida) in Central Asia. Zoological Zhurnal 43(1): 17-27.

Brooks HK. 1962. On the fossil Anaspidacea, with a revision of the classification of the Syncarida. Crustaceana 4(3): 229-242.

Boutin C, Coineau N. 1987. Iberobathynella sur le continent africain. Implications paléogéographiques. Comptes-Rendus Hebdomadaires de l'Académie des Sciences de Paris 304 Série III, 13: 355-358.

Boutin C, Coineau N. 1990. "Regression model”, "Modèle Biphase" d'évolution et origine des micro-organismes stygobies interstitiels continentaux.Revue Micropaléontology 33(3-4): 303-322.

Brooks HK. 1962. On the fossil Anaspidacea, with a revisión 
of the classification of the Syncarida. Crustaceana 4: 239242.

Camacho AI. 1986. A new species of the genus Hexabathynella (Syncarida, Bathynellacea, Parabathynellidae) from Spain. Bijdragen tot Dierkunde 56(1): 123-131.

Camacho AI. 2003. An overview of the distribution of the Parabathynellidae (Crustacea Syncarida Bathynellacea) on the Iberian Peninsula and Balearic Islands. Graellsia 59(1): 63-78

Camacho AI. 2005a. Disentangling an Asian puzzle: two new bathynellid (Crustácea, Syncarida, Parabathynellidae) genera from Vietnam. Journal of Natural History 39(31): 2861-2886.

Camacho AI. 2005b. Expanding the taxonomic conundrum: three new species of groundwater crustacean (Syncarida, Bathynellacea, Parabathynellidae) endemic to the Iberian Peninsula. Journal of Natural History 39(21): 1819-1838.

Camacho AI. 2007. The first record of the genus Vejdovskybathynella Serban and Leclerc, 1984 (Syncarida, Bathynellacea, Bathynellidae) in the Iberian Peninsula: three new species. Journal of Natural History 41: 2817-2841.

Camacho AI, Coineau N. 1989. Les Bathynellacea d'Espagne: Répartition et Biogéographie. Mémories de Biospéologie 16(43): 111-124.

CamachoAI,Hancock P.2010.Anew record of Parabathynellidae (Crustacea, Bathynellacea) in Australia: a new genus and species from New South Wales. Journal of Natural History 44(17-18): 1081-1094.

Camacho AI, Serban E. 1998. Tribu des Iberobathynellini nov., diagnoses des taxa nouveaux (Parabathynellidae, Bathynellacea, Podophallocarida). Travaux de l'Institut de Spéologie "Émile Racovitza” 34(1995): 15-75.

Camacho AI, Valdecasas AG. 2008. Global diversity of syncarids (Syncarida; Crustacea) in freshwater. Hydrobiologia 595(1): 257-266.

Camacho AI, Serban E, Guil N. 2000. Phylogenetical review and biogeographic remarks on the interstitial and subterranean freshwater iberobathynells (Crustacea, Syncarida, Parabathynellidae). Journal of Natural History 34: 563-585.

Camacho AI, Trontelj P, Zagmajster M. 2006. First record of Bathynellacea (Crustacea, Syncarida, Parabathynellidae) in China: a new genus. Journal of Natural History 40(29-31): 1747-1760.

Camacho AI, Waitiroyram S, Brancelj A. 2011. The first record of bathynellids from Thailand: A new genus and species of Parabathynellidae (Crustacea, Syncarida, Bathynellacea). Journal of Natural History 45(45-46): 2841-2854.

Camacho A.I., Dorda B.A., Rey, I. 2012. Undisclosed taxonomic diversity of Bathynellacea (Malacostraca: Syncarida) in the Iberian Peninsula revealed by molecular data. Journal of Crustacean Biology 32(5): 816-826. DOI: 10.1163/193724012X638473.

Camacho AI, Rey I, Dorda BA, Machordon A, Valdecasas AG. 2002. A note on the systematic position of the Bathynellacea (Crustacea, Malacostraca) using molecular evidence. Contribution to Zoology 71(4): 123-129.

Camacho AI, Newell RL, Crete Z, Dorda BA, Casado A, Rey I. 2015. Northernmost discovery of Bathynellacea (Syncarida: Bathynellidae) with description of a new species of Pacificabathynella from Alaska (USA). Journal of Natural History 50: 583-602.
Camacho AI, Dorda BA, Sanchez-Chillón B, Rey I. 2017. The collection of Bathynellacea specimens of MNCN (CSIC) Madrid: microscope slices and DNA extract. Zookeys 678: 31-63. doi: 10.3897/zookeys.678.11543.

Chappuis PA. 1915. Bathynella natans und ihre Stellung im System. Zoological Jahrbuch XL: 147-176.

Chappuis PA. 1926. Parabathynella stygia n.g. n.sp. nouveau crustacé cavernicole de la Serbie Orientale. Buletinul Societatii de Stiinte din Cluj II: 7-10.

Cho J-L. 2001. Phylogeny and zoogeography of three new species of the genus Hexabathynella (Crustacea, Malacostraca, Bathynellacea) from North America. Zoologica Scripta 30(2): 145-157.

Cho J-L, Schmnike HK. 2006. A phylogenetic review of the genus Hexabathynella Schminke, 1972 (Crustacea, Malacostraca, Bathynellacea): with a description of four new species. Zoological Journal of the Linnean Society 147: 71-96.

Cho J-L, Hwang IS, Nam EJ. 2008. Nipponbathynella also in South-Korea (Bathynellacea, Syncarida). Journal Crustacean Biology 28(4): 721-726.

Cho J-L, Kry M, Chhenh K. 2015. A new giant parabathynellid from Cambodia (Syncarida: Bathynellacea). Journal Crustacean Biology 35(4): 559-569.

Coineau N, Boutin C. 1992. Biological processes in space and time: colonization. evolution and speciation in interstitial stygobionts. 423-451. In: Camacho AI (Ed). The Natural History of Biospeleology. Monografías del MNCN, 7(CSIC), Madrid.

Coineau N, Camacho AI. 2013. Superorder Syncarida Packard, 1885. Chapter 50: 357-449. In: Von Vaupel Klein JC, Charmantier-Daires M, Schram FR (Eds). (Founded by Grassé P-P). Treatise on Zoology-Anatomy, Taxonomy, Biology. The Crustacea. Traité de Zoologie, Vol. 4, Part A. Koninklijke Brill NV ISBN 978900417809 0. Leiden.

Coineau N, Serban E. 1978. Sur les Parabathynellidae (Podophallocarida, Bathynellacea) d'Afrique du Sud, Ctenophallonella mutlumuviensis n. g. n. sp. Bulletin du Muséum d'Histoire Naturelle, Paris 510, Zool 351: 71-89.

Darriba D, Taboada GL, Doallo R, Posada D. 2012.jModelTest 2: more models, new heuristics and parallel computing. Nature Methods 9: 772. doi:10.1038/nmeth.2109

Delamare Deboutteville C, Coineau N, Serban E. 1975. Découverte de la famille des Parabathynellidae (Bathynellacea) en Amerique du Nord: Texanobathynella bowmani n.g.n.sp. C R hebd Acad Sci Paris Sèr D 280: 22232226.

Drummond AJ, Suchard MA, Xie D, Rambaut A. 2012. Bayesian phylogenetics with BEAUti and the BEAST 1.7. Molecular Biology and Evolution 29: 1969-1973.

Folmer O, Black M, Hoeh W, Lutz R, Vrijenoek R. 1994. DNA primers for amplification of mitochondrial cytochrome $\mathrm{c}$ oxidase subunit 1 from diverse metazoan invertebrates. Molecular Marine Biology and Biotechnology 3: 294-299.

Gibbons AD, Barckhausen U, van den Bogaard P, Hoernie K, Werner R, Whittaker JM, Muller RD. 2012. Constraining the Jurassic extent of Greater India: Tectonic evolution of the West Australian margin. Geochemistry Geophysics Geosystems 13(5): 1-25. DOI:10.1029/2011GC003919.

Gilbert MT, Moore W, Melchior L, Worobey M. 2007. DNA extraction from dry museum beetles without conferring 
external morphological damage. PLOS ONE 2: e272.

Giribet G, Carranza S, Baguña J, Riutort M, Ribera C. 1996. First molecular evidence for the existence of a Tardigrada + Arthropoda clade. Molecular Biology and Evolution 13(1): $76-84$.

Golonka J. 2004. Plate tectonic evolution of the southern margin of Eurasia in the Mesozoic and Cenozoic. Tectonophysics 381(1): 235-273.

Golonka J. 2007. Late Triassic and Early Jurassic palaeogeography of the world. Palaeogeography Plaeoclimatology Palaeoecology 244: 297-307.

Golonka J, Gaweda A. 2012. Plate tectonic evolution of the southern margin of Laurussia in the Paleozoic . pp. 261-282. In: Sharkov E (Ed). Tectonics-Recent Advances.

Grobben K. 1905. Lehrbuch der Zoologie, begründet von C. Claus, 1 neubearbeitet von Dr Karl Grobben. Essen, Publisher unknown, Marburg, Vol. 1 7th Edn, 995 pp (N. G. Elwert'sche Verlagsbuchhandlung, Marburg in Hessen).

Hall R. 2012. Late Jurassic-Cenozoic reconstructions of the Indonesian region and the Indian Ocean. Tectonophysics 570: $1-41$.

Hutchison CS. 2014. Tectonic evolution of Southeast Asia. The Bulletin of the Geological Society of Malaysia 60: 1-18

Jankowskaja AI. 1964. Relict Crustaceans of coastal bottom waters of the Lake Issyk-Kul (North Tienshan). Zoologicheskii Zhurnal 43(7): 975-986.

Jankowskaja AI. 1972. New species of Parabathynella (Crustácea, Syncarida) and Microcharon (Isopoda) from interstitial waters of the desert Kisilkum (in the fauna of subterranean waters of Middle Asia). Trud Zool Inst Acad Nauk USSR 51:131-138.

Katoh K, Toh H. 2008. Recent developments in the MAFFT multiple sequence alignment program. Briefings in Bioinformatics 9: 286-298.

Krobicki M, Golonka J, The Hung K. 2008. Major Tectonic Events and Plates of Northwest Vietnam. Proceedings of the International Symposia on Geoscience Resources and Environments of Asian Terranes (GREAT 2008), 4th IGCP 516, and 5th APSEG.

Krobicki M, Hnylko O, Feldman-Olszewska A, Iwańczuk J. 2014. Tectono-Stratigraphic Position of the Kaminnyi Potik Unit in the Ukrainian Carpathians and Volcanogenic Rocks of Mt Chyvchyn. Chapter 102, 10.1007/978-3-31904364-7_102. In: Rocha R, Pais J, Kullberg JC, Finney S (Eds). Strati 2013-2014, First International Congress on Stratigraphy At the Cutting Edge of Stratigraphy. Springer Geology, e-Book collection Earth and Environmental Science.

Lanfear R,Calcott B,Ho SYW, Guindon S. 2012.PartitionFinder: combined selection of partitioning schemes and substitution models for phylogenetic analyses. Molecular Biology and Evolution 29: 6.

Lanfear R, Calcott B, Kainer D, Mayer C, Stamatakis A. 2014. Selecting optimal partitioning schemes for phylogenomic datasets. BMC Evolutionary Biology 14:1.

Lawver LA, Gahagan LM, Coffin MF. 1992. The development of paleoseaways around Antarctica. In: Kennett, J.P. and Baron J. (Eds). The Antarctic Paleoenvironment: A perspective on global change. American Geophysical Union, Antarctic Research Series 56: 7-30

Lawver LA, Dalziel JWD, Gahagan LM. 2007. Atlas of plates reconstruction, (750 Ma to present day). University of Texas Institute for Geophysics, Austin.

Little J, Camacho, AI. 2017. Morphological and molecular characterisation of a new genus and new species of Parabathynellidae (Crustacea, Syncarida) in Queensland, Australia. Invertebrate Systematics 31: 208-219.

Macdonald D, Gomez-Perez I, Franzese J, Spalletti L, Lawver L, Gahagan L, Dalzielc I, Thomras C, Trewin N, Malcom H, Paton D. 2003. Mesozoic break-up of SW Gondwana: implications for regional hydrocarbon potential of the southern South Atlantic. Marine and Petroleum Geology 20(3): 287-308.

Maddison WP, DR Maddison. 2015. Mesquite: a modular system for evolutionary analysis. Version $3.04 \mathrm{http}: / /$ mesquiteproject.org

Maderspacher F. 2012. Evolution: Drift Will Tear Us Apart. Current Biology 22 No 21. doi.org/10.1016/j. cub.2012.10.001.

Morimoto Y. 1959. Bathynellids of the Amami group of the Ryu-Kyu Islands (Syncarida, Bathynellacea). Memoirs of the College of Science, University of Kyoto, Series B 26: 269-280.

Morimoto Y. 1963. Occurrence of a Giant Parabathynella in Southeastern Kyushu, Japan. Annotationes Zoologicae Japonenses 36(3): 161-165.

Morimoto Y. 1970. Results of the Speleological Survey in South Korea 1966. XXI Bathynellid Crustaceans (Syncarida) from South Korea. Bulletin of the National Science Museum Tokyo 13(2): 149-184.

Morimoto Y. 2002. Nipponbathynella uozumii sp. nov., a new Parabathynellid (Crustacea, Malacostraca, Bathynellacea) from Japan. Journal of the Speleological Society of Japan 27: 17-22.

Morimoto Y, Miura Y. 1957. Allobathynella japonica gen, et sp.nov., a new Bathynellid from Japan. Proceedings of the Japan Academy 33(3):145-148.

Nam E-J, Cho J-L. 2014. A new genus and two new species of Parabathynellidae from Cambodian interstitial (Bathynellacea, Syncarida). Proceedings of the Biological Society of Washington 127 (1): 229-247.

Noodt W. 1963. Anaspidacea (Crustacea, Syncarida) in der südlichen Neotropis. Verhandlungen der Deutschen Zoologische Gesellschaft in Wien: 568-578.

Noodt W. 1965. Natürliches System und Biogeographie der Syncarida. Gewässer und Abwässer 37/38: 77-186.

Papadopoulou A, Anastasiou I, Vogler AP. 2010. Revisiting the insect mitochondrial molecular clock: the mid-Aegean trench calibration. Molecular Biology and Evolution 27: 1659-1672.

Park J-G, Cho J-L. 2008. A preliminary inquiry into an Asian topsy-turvy dom, Allobathynella with the description of a new species from South Korea and redescription of A. japonica (Crustacea, Syncarida, Parabathynellidae). Journal of Natural History 42(1-4): 223-238.

Park J-G, Cho J-L. 2013. A new genus and two new species of Parabathynellidae (Malacostraca: Syncarida) from SouthKorea. Journal Crustacean Biology 33: 866-881.

Park J-G, Cho J-L. 2015. Two new species of Arisubathynella Park and Eun, 2012 (Malacostraca: Syncarida: Parabathynellidae) from South Korea. Journal Crustacean Biology 35(2):241-254. 
Park J-G, Cho J-L. 2016. Fourteen new species of Allobathynella Morimoto and Miura, 1957 from South Korea: with a redescription of A. coreana Morimoto, 1970 (Crustacea, Bathynellacea, Parabathynellidae). Journal of Species Research 5(1): 49-156.

Park J-G, Eun Y. 2012. A new species and a new genus of Parabathynellidae (Crustacea, Syncarida) from South Korea. Zootaxa 3368: 291-299.

Perina G, Camacho AI. 2016. Permanent slides for morphological studies of small crustaceans: Serban's method and its variation applied on Bathynellacea (Malacostraca). Crustaceana 89(10): 1161-1173.

Posada D, Buckley TR. 2004. Model selection and model averaging in phylogenetics: advantages of Akaike information criterion and Bayesian approaches over likelihood ratio tests. Systematic Biology 53: 793-808.

Ranga Reddy Y. 2002. Habrobathynella nagarjunai n.sp., the second representative of Bathynellacea (Crustacea, Syncarida) from groundwaters of South India. Hydrobiologia 470: 37-43.

Ranga Reddy Y. 2004. Existence of the order Bathynellacea (Crustacea, Syncarida) in South Asia: a new species of genus Habrobathynella Schminke 1973, from river Pennar, South India. Journal of the Bombay Natural History Society 101(2): 277-284.

Ranga Reddy Y. 2006. First Asian report of the genus Chilibathynella Noodt, 1963 (Bathynellacea, Syncarida), with the description and biogeographic significance of a new species from Kotumsar Cave, India. Zootaxa 1370: 23-37.

Ranga Reddy Y. 2011. Gondwanan heritage in groundwater crustaceans of peninsular India. Current Science 101: 156158.

Ranga Reddy Y, Schminke HK. 2005. Morphological diversity of habrobathynellids (Parabathynellidae, Bathynellacea) in India, with the description of a new species. Journal of Natural History 39(24): 2217-2224.

Ranga Reddy Y, Schminke HK. 2009. Co-ocurrence of two species of the genus Habrobathynella Schminke, 1973 (Malacostra, Bathynellacea) in sandy sediments of the River Godavari, southeastern India, with the description of a new species. Crustaceana 82(4): 475-485.

Ranga Reddy Y, Totakura VR. 2010. A taxonomic revision of the genus Habrobathynella Schminke, 1973, with the description of four new species from southeastern India (Crustacea, Malacostraca, Bathynellacea). Zootaxa 2532: $1-54$.

Ranga Reddy Y, Totakura VR. 2015. Atopobathynella paraoperculata n. sp.(Syncarida, Bathynellacea, Parabathynellidae) from the River Krishna, Southeastern India. Crustaceana 88(3): 343-358.

Ranga Reddy, Y, Drewes J, Schminke HK. 2008. A new species of the genus Atopobathynella Schminke, 1973 (Crustacea, Syncarida, Bathynellacea) from the hyporheic zone of the River Godavari, South India. Zootaxa 1829: 52-60.

Ranga Reddy Y, Shaik S, Totakura VR. 2014. Habrobathynella borraensis $\mathrm{n} . \mathrm{sp}$. (Syncarida, Bathynellacea: Parabathynellidae) from the Borra Caves of Southeastern India, with a note on the taxonomic significance of paragnath morphology. Journal of Crustacean Biology 34(1): 90-106. DOI: 10.1163/1937240X00002210 .

Raval U, Veeraswamy K. 2003. India-Madagascar separation: breakup along a pre-existing mobile belt and chipping of the craton. Gondwana Research 6: 467-485. http://dx.doi. org/10.1016/S1342-937X(05)70999-0

Riccardi AC. 1991. Jurassic and Cretaceous marine connections between the southeast Pacific and Tethys. Palaeogeography Plaeoclimatology Palaeoecology 87(1-4): 155-189.

Ronquist F, Teslenko M, Van der Mark P, Ayres DL, Darling A, Höhna S, Larget B, Liu L, Huelsenbeck JP. 2012. MrBayes 3.2: efficient Bayesian phylogenetic inference and model choice across a large model space. Systematic Biology 61(3): $539-542$.

Sars GO. 1929. Fauna of the Batu Caves, Selangor. Viii. Description on a remarkable cave-crustacean, Parabathynella malaya G.O. Sars, sp. nov., with general remarks on the family Bathynellidae. Journal of the Federated Malay States Museums 14: 339-351.

Schminke HK. 1972. Hexabathynella halophila gen. n., sp. n. und die Frage nach der marinen Abkunft der Bathynellacea (Crustacea, Malacostraca). Marine Biology 15: 282-287.

SchminkeHK.1973.Evolution,SystemundVerbreitungsgeschichte der Familie Parabathynellidae (Bathynellacea, Malacostraca). Akademie der Wissenschaften und der Literatur Mainz, Mathematisch-Naturwissenschaftliche Klasse, Mikrofauna des Meeresbodens 24: 1-192.

Schminke HK. 1974. Mesozoic intercontinental relationship as evidenced by Bathynellid Crustacea (Syncarida: Malacostraca). Systematic Zoology 23 (2): 157-164.

Schminke HK. 1988. A new genus and species of Syncarida (Crustácea: Malacostraca) from Borneo. Journal of Natural History 22(3): 631-637.

Schminke HK. 2011. Arthropoda: Crustacea: Malacostraca: Bathynellacea: Parabathynellidae. pp 244. In: Flora and Fauna de Korea. Invertebrate Fauna of the World. National Institute of Biological Resources, Ministry of Environment, Republic of Korea. V 21(1).

Schram F. 1977. Paleozoogeography of late Paleozoic and Triassic Malacostraca. Systematic Zoology 26: 367-379.

Schram F. 1981. Late Paleozoic crustacean communities. Journal of Paleontology 55(1): 126-137.

Schram FR. 1984. Fossil Syncarida. Transaction of the San Diego Society of Natural History 20: 189-246.

Schram FR, Hof CHJ. 1998. Fossils and the interrelationship of major Crustacean group. In: Edgecombe CD (Ed.). Artropod Fossils and Phylogeny. Columbia University Press, New York, 233-302.

Serban E. 1972. Bathynella (Podophallocarida, Bathynellacea). Travaux de l'Institut de Spéologie "Émile Racovitza" 11: 11225.

Serban E. 1980. La mandibule et l'individualisation des ensembles évolutifs majeurs dans l'ordre des Bathynellacea (Malacostraca: Podophallocarida). Bijdragen tot de Dierkunde, 50(1): 155-189.

Serban, E. 1985. Le développement postembryonnaire chez Gallobathynella coiffaiti (Delamare) (Gallo-bathynellinae: Bathynellidae: Bathynellacea). Travaux de l'Institut de Spéologie "Émile Racovitza" 24: 47-61.

Serban E. 1994. Issykkulibathynella n.g. et son espècetype I. tianschanica (Jankowskaja) (Parabathynellidae, Bathynellacea, Podophallocarida). Travaux de l'Institut de Spéologie "Émile Racovitza” 23: 31-48.

Serban E, Coineau N. 1975. Haplophallonella heterodonta n.g., 
n. sp.. Parabathynellidé (Podophallocarida, Bathynellacea) d'Afrique (Côte d'Ivoire). Travaux de l'Institut de Spéologie “Émile Racovitza” 14: 51-70.

Serban E, Coineau N. 1982. Lamtobathynella pentodonta n. g. n. sp.. Leptobathynellidé nouveau d'Afrique (Côte d'Ivoire) (Malacostraca, Bathynellacea). International Journal of Speleology 10(3): 69-74.

Serban E, Coineau N. 1990. Données concernant le développement pst-embryonnaire dans la famille des Parabathynellidae Noodt (Bathynellacea, Podophallocarida, Malacostraca). Travaux de l'Institut de Spéologie "Émile Racovitza" 29: 3-24.

Serban E, Coineau N. 1994. Racovitzaibathynella emilei n.g. n.sp. et $R$. transvaalensis n.sp. (Bathynellacea, Podophallocarida). Travaux de l'Institut de Spéologie "Émile Racovitza" 33: 11-30.

Simon C, Frati F, Beckenbach A, Crespi B, Liu H, Flook P. 1994. Evolution, weighting, and phylogenetic utility of mitochondrial gene-sequences and a compilation of conserved polymerase chain-reaction primers. Annalsof the Entomological Society of America 87: 651-701.

Stadler T. 2009. On incomplete sampling under birthdeath models and connections to the sampling-based coalescent. Journal of Theoretical Biology 261: 58-66.

Stamatakis A. 2014. RAxML version 8: a tool for phylogenetic analysis and post-analysis of large phylogenies. Bioinformatics 30(9): 1312-1313.
Thomson GM. 1893. Notes on Tasmanian Crustacea, with descriptions of new species. Paper and Proceedings of the Royal Society of Tasmania 1892: 45-76.

Totakura VR, Ranga Reddy Y. 2014. Three new species of the genus Habrobathynella Schminke, 1973 (Syncarida, Parabathynellidae) from the peninsular India. Zootaxa 3826(1): 139-168.

Ueno M. 1952. Three new species of Bathynellidae (Syncarida) found in subterranean waters of Japan. Annotationes Zoologicae Japonenses 25(1-2): 317-328.

Ueno M. 1956. More species of Parabathynella from Japan. Annotationes Zoologicae Japonenses 29(2): 109-115.

Ueno M. 1961. A new japanese bathynellid. Crustaceana 1(2): 85-88.

Yilmaz PO, Norton IO, Leary D, Chuchla RJ. 1996. Tectonic evolution and paleogeography of Europa. 47-60. In: Zieglers PA, Howath F (Eds). Peri-Tethys Memoirs 2: Structure and Prospects of Alpine Bassins and Forelands (Paris: Mémories du Museum National d'Historie Natural).

Received: 4 May 2018

Revised and accepted: 3 September 2018

Published online: 9 November 2018

Editor: R. Vonk 


\section{Appendix 1}

\section{Systematic account}

The three new species described here belong to the genus Paraeobathynella. Previously only the type species P. vietnamensis Camacho, 2005 was known from the Hang Trinh $\mathrm{Nu}$ cave in Vietnam. The three new species from Thailand were found: $P$. ratensis n. sp. 29.10.2015 in the Rat cave, 55 specimens (14 males, 16 females and 25 juveniles); P. siamensis $\mathrm{n}$. sp. 23.10.2015 in the Khao Krot cave, 41 specimens (22 males, 17 females and two juveniles) and $P$. hanjavanitiana n. sp. 29.10.2015 in the Khao Plu cave, 47 specimens (21 males, 19 females and seven juveniles).

The morphological descriptions are based on the holotype (male) and type series. Molecular analysis is based on DNA extract (whole specimens and abdomen of the specimens used in morphological study) all of these are part of the type series (see Tables 1,2).

\section{Paraeobathynella Camacho, 2005}

Amended diagnosis (after Camacho, 2005)

Antennule (AI) 7- to 9-segmented, with subterminal aesthetascs on terminal segment. Antenna (AII) 7-segmented; fourth segment naked. Mandible (Md) pars molaris protruding. Maxillule (Mx.I) proximal endite with four claws; distal endite with seven teeth. Exopod of thoracopods (Th) I-VII with more than two segments (3- to 9-segmented); basipod of Th I with two setae. Male Thoracopod VIII large; basipod trapezoidal with a crest-like protuberance on the inner lateral edge; endopod well developed, with two terminal setae; exopod very large, longer than wide, overhanging basipod and positioned distally; inner lobe completely integrated into basal region, not exceeding dentate lobe; rounded outer lobe not

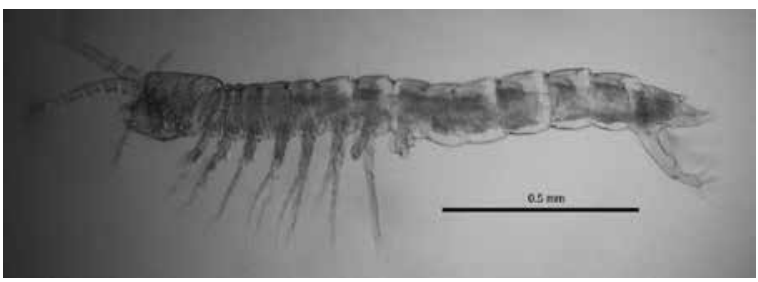

Figure 5. Habitus of Paraeobathynella ratensis n. sp. Male. Scale bar: in $\mathrm{mm}$.

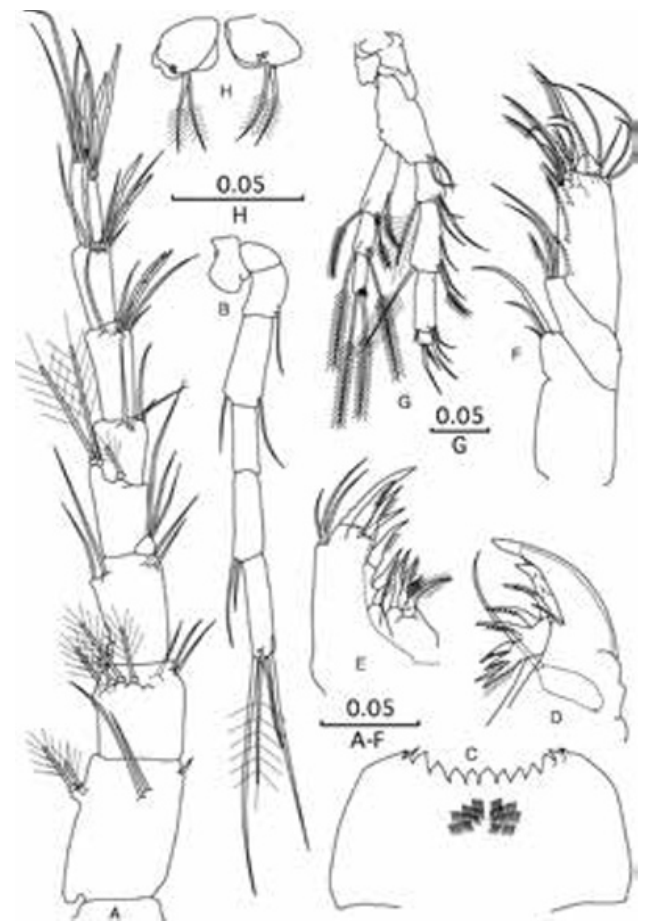

Figure 6. Paraeobathynella ratensis n. sp. Male holotype. A: Antennule; B: Antenna; C: Labrum; D: Mandible; E: Maxillule; F: Maxilla; G: Thoracopod I; H: Female Thoracopod VIII. Scale bar: in $\mathrm{mm}$.

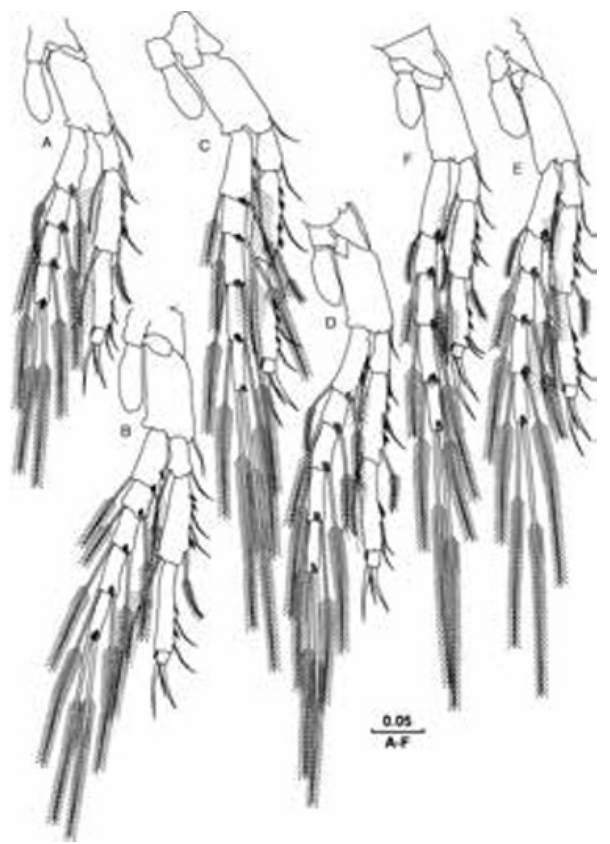

Figure 7. Paraeobathynella ratensis n. sp. Male holotype: A: Thoracopod II; B: Thoracopod III; C: Thoracopod IV; D: Thoracopod V; E: Thoracopod VI; F: Thoracopod VII. Scale bar: in $\mathrm{mm}$. 


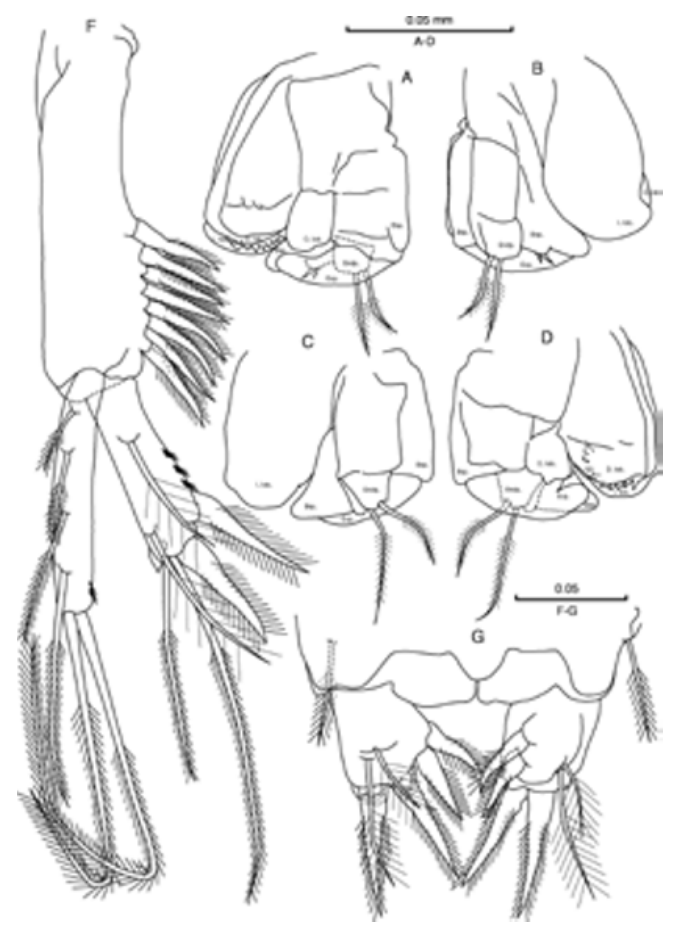

Figure 8. Paraeobathynella ratensis n. sp. Male holotype. A: Thoracopod VIII (lateral internal view); B: Thoracopod VIII (latero-external view); C: Thoracopod VIII (latero-frontal view); D. Thoracopod VIII (latero-caudal view); E: Uropod (lateral view); F: Pleotelson and furca (dorsal view). Scale bar: in $\mathrm{mm}$.

fused with basipod. Female Th VIII large, almost square, with or without small denticles and with 2 long terminal setae. Pleopods not developed. Ventral seta of pleotelson placed near base of furca. Sympod of uropod with subequal spines; endopod with two spines and two apical setae.

Type species: Paraeobathynella vietnamensis Camacho, 2005

\section{Paraeobathynella ratensis Camacho and Watiroyram n. sp. (Figs 5-8) \\ http://zoobank.org/urn:lsid:zoobank.org:act: \\ AF660AB2-7274-42D1-A8C0-20C0174BAB1D}

\section{Material examined (Tables 1, 2)}

Type material. The specimens were collected at Rat Cave, Kapang subdistrict, Thung Song district, Nakhon Si Thammarat province, Southern Thailand (08 $02^{\prime} 48.244^{\prime \prime} \mathrm{N} 9^{\circ} 43^{\prime} 42.48^{\prime \prime} \mathrm{E} ; 89$ m a.s.l) on 29.10.2015. Holotype male (ARTP Collection MNCN20.04/19825) collected together with 14 males, 16 females and 25 juveniles. The morphological type series contains 11 slides (five males and six females; ARTP Collection MNCN20.04/19826-19836) together with DNA extractions of seven whole specimens and seven abdomens (DNA types: MNCN/ADN5467254685). Description is based on all adult specimens of the type series. All drawings in description correspond to the male holotype except the female Th VIII paratype. Short diagnosis: 8-segmented AI; 7-segmented AII; Md, pars incisiva 5 teeth, pars molaris 7 teeth; MxII, setal formula, 3/3/11/4; basipod Th III-VII, 1 seta; exopod Th I, 3-4 segmented; exopod Th II-VII, 4-6 segmented; absent pleopods; uropod, 7-9 similar spines on sympod, 6 setae on exopod, 2 spines and 4 setae on endopod; furca, 4-5 spines; protruded small anal operculum.

\section{Description}

Body: Total length of holotype $1.66 \mathrm{~mm}$. Total length of males $(n=6)$ : $1.21-1.72 \mathrm{~mm}$; females $(n=6)$ : 1.29-1.86 mm. Body elongate (Fig. 5. Head longer than broad.

Antennule (Fig. 6A): 8-segmented, not sexuallydimorphic; length of proximal four segments combined higher than four distal segments combined; segment 2 short, almost square; inner flagellum almost triangular; three distal segments similar in length; segment 5 short, lacking aesthetascs; segment 6 with 2 aesthetascs; segments 7 and 8 each with three aesthetascs; aesthetascs on terminal segment disposed subdistally, one of them longer than rest. Setation on segments as figured.

Antenna (Fig. 6B): Slightly longer than first four antennulary segments combined. 7-segmented: proximal three segments short; segments 4,6 and 7 similar in length; segment 5 as $2 / 3$ length of segment 4;. Setal formula as: $0 / 0 / 1+0 / 1+1 / 0 / 0+2 / 4(1)$.

Labrum (Fig. 6C): Concave, with 13 teeth; all teeth unicuspid except outermost tooth at each side, which are bicuspided and more slender than rest. Ventral surface with several rows of spinules.

Mandible (Fig. 6D): Pars incisiva with 5 well developed teeth and one small proximal spine-like tooth; pars molaris with 7 claws, 5 of them strong and denticulate, 2 most proximal joined basally, setulose and more slender than rest; mandibular palp unsegmented, with long simple seta not exceeding pars incisiva.

Maxillule (Fig. 6E): Proximal endite with 4 of unequal claws; distal endite with 7 claws, of which two more distal smooth, rest denticulate; 3 simple setae implanted subdistally on outer margin of endite as figured. 
Maxilla (Fig. 6F): 4-segmented, with 3 setae on proximal segment; second segment with 2 long and one shorter setae; third segment elongate with 11 setae; distal segment with one strong terminal, one subterminal and 2 lateral setae.

Thoracopods I-VII (Figs. 6G; 7A-F): Well developed, length slightly increasing from Th I to Th III; last 5 Ths similar in size. Coxopod with well developed epipodite on Th II-VII, latter reaching slightly more than half length of corresponding basipod. Basipod similar in length in all thoracopods except Th I, which is slightly shorter than rest; basipod of Th I-II with 2 lateral setae and only one on rest of thoracopods. Exopod of Th I 3-segmented (Fig. 6G), 4-segmented on Th II (Fig. 7A), 5-segmented on rest of thoracopods (Fig. 7B to F); exopod shorter than corresponding endopod in Th I-II, of similar length in Th III-VI, and longer in Th VII; all exopodal segments with 2 barbed setae except in Th I, which bears 3 on first segment; one cluter of ctenidia at base of each seta of exopod as figured. Endopod 4-segmented; first segment similar in all Ths, half length of second segment; second and third segments long and similar in length in all Ths except Th I, which is shorter than rest; fourth segment reduced, with 2 strong smooth claws of unequal length and one simple seta. Setal formula of endopods as: Th I, $3+1 / 3+1 / 2+1 / 3(1)$; Th II, $1+1 / 2+1 / 3+1 / 3(1)$; Th III, $1+1 / 3+1 / 2+1 / 3(1)$; Th IV-VII, $1+1 / 2+1 / 2+1 / 3(1)$; outer seta on first and second segment of Th I-VII plumose.

Male Thoracopod VIII (Fig. 8A-D): Large, massive, almost square; basal region massive; inner lobe completely integrated into basal region, barely exceeding distal end of dentate lobe; basipod with one distal protuberance resembling a crest with 2 small teeth on the inner lateral edge, which exceeds end of internal lobe. Endopod large and almost square, with 2 long barbed setae. Exopod large, longer than wide, overhanging basipod and outer lobe; outer lobe rectangular, not fused with basipod and not exceeding end of outer side of basipod; dentate lobe overlapped by inner lobe, with large teeth on rounded distal end.

Female Thoracopod VIII (Fig. 6H): Large with smooth cuticle, rounded, with 2 long distal barbed setae and 2 small teeth .

Pleotelson (Fig. 8F): Anal operculum slightly pronounced, with rounded tip; ventral seta barbed, reaching up to midway of furcal ramus.

First pleopods: Absent.

Uropod (Fig. 8E): Sympod longer than rami, 3.5 times as long as wide, with 8 barbed spines of similar size along distal half of inner margin. Endopod sligthly shorter than exopod, with 2 strong barbed spines, 2 barbed setae and one strong denticle on distal margin, and with 2 plumose setae along outer margin, latter two exceeding in length distal end of endopod; three groups of ctenidia on medial margin of segment as figured. Exopod with 2 barbed setae distally and 4 barbed setae along outer margin; one group of ctenidia on distomedial angle of segment.

Furca (Fig. 8F): Each ramus almost square, with 4 strong barbed spines, 2 terminal ones slightly longer and thicker than rest. Dorsal side of furcal rami each with the 2 plumose setae - characteristic of family Parabathynellidae- of unequal length, one of which reaching tip of terminal spine.

Etymology. The specific name, ratensis, refers to Rat Cave, where the new species was found. The epitheton is a noun in the genitive singular masculine.

\section{Paraeobathynella siamensis Camacho and Watiroyram n. sp. (Figs 9-14)}

http://zoobank.org/urn:lsid:zoobank.org:act:

ADA728EB-4516-4BB0-9B65-86E42C770548

\section{Material examined (Tables 1,2)}

Type material: The specimens were collected at Khao Krot Cave, Kuanthong subdistrict, Khanom district, Nakhon Si Thammarat province, Southern Thailand $\quad\left(08^{\circ} 01^{\prime} 22.50^{\prime \prime} \mathrm{N} \quad 99^{\circ} 34^{\prime} 36.09 \quad \mathrm{E} ; \quad 45\right.$ $\mathrm{m}$ a.s.1.) on 23.10.2015. Holotype male (ARTP Collection MNCN20.04/19843) collected together with 41 specimens ( 22 males, 17 females and two

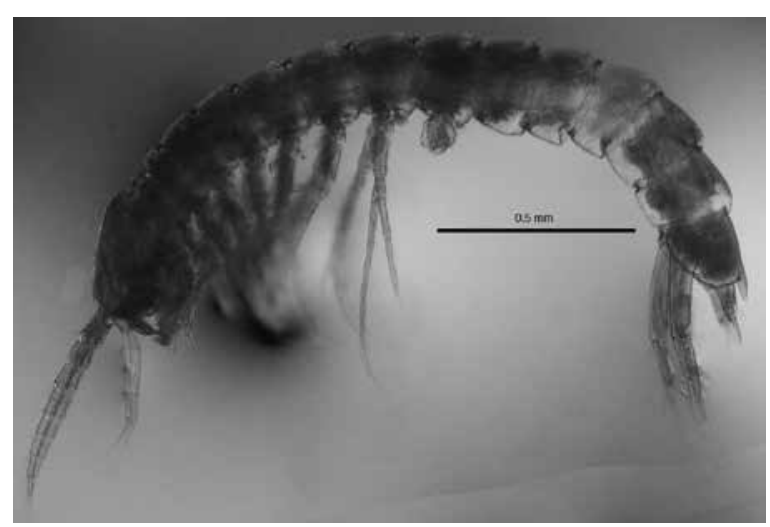

Figure 9. Habitus of Paraeobathynella siamensis n. sp. Scale bar: in $\mathrm{mm}$. 


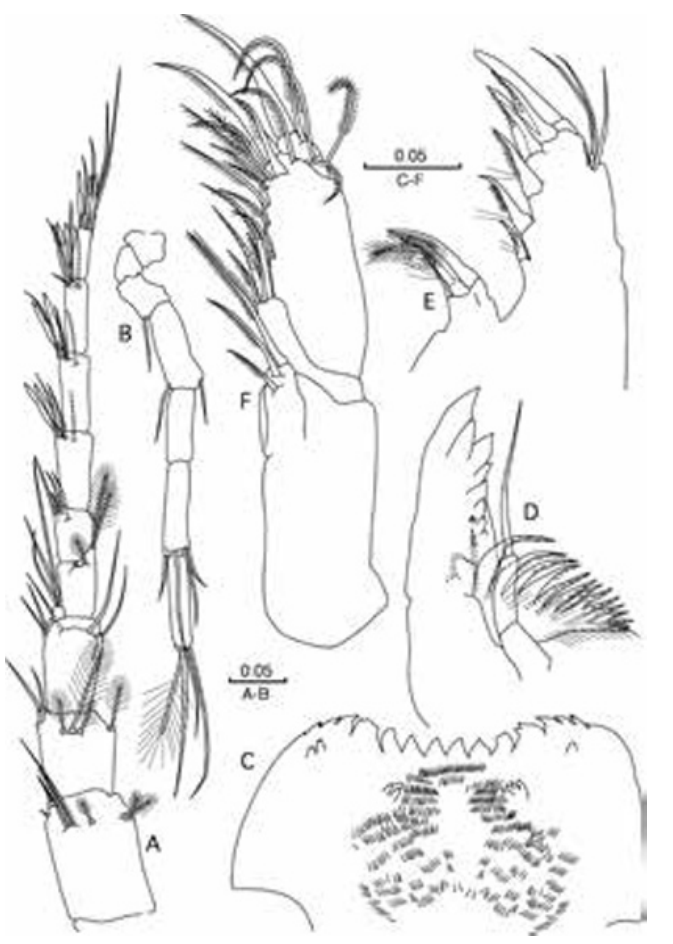

Figure 10. Paraeobathynella siamensis n. sp.Male holotype. A: Antennule; B: Antenna; C: Labrum; D: Mandible; E: Maxillule; F: Maxilla. Scale bar: in $\mathrm{mm}$.

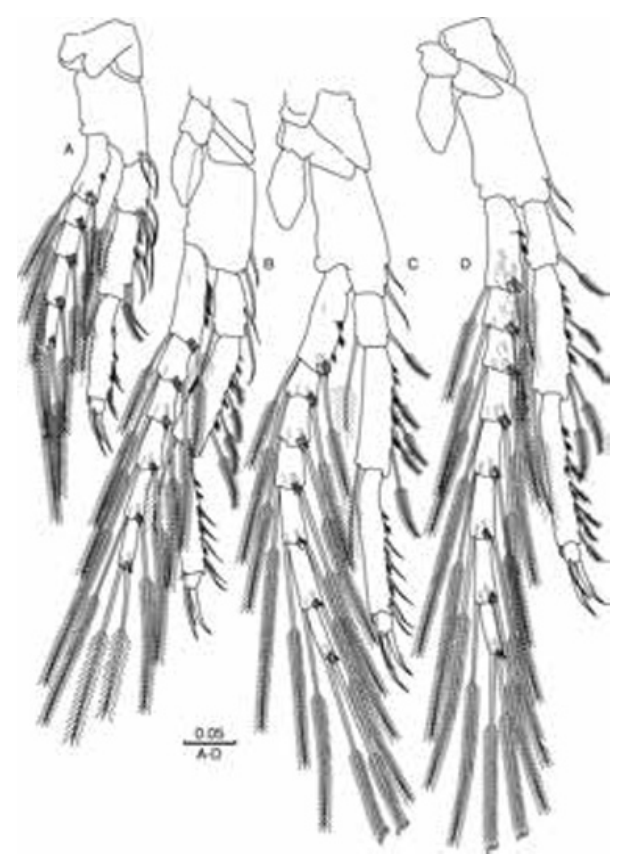

Figure 11. Paraeobathynella siamensis n. sp.Male holotype. A: Thoracopod I; B: Thoracopod II; C: Thoracopod III; D: Thoracopod IV. Scale bar: in mm.

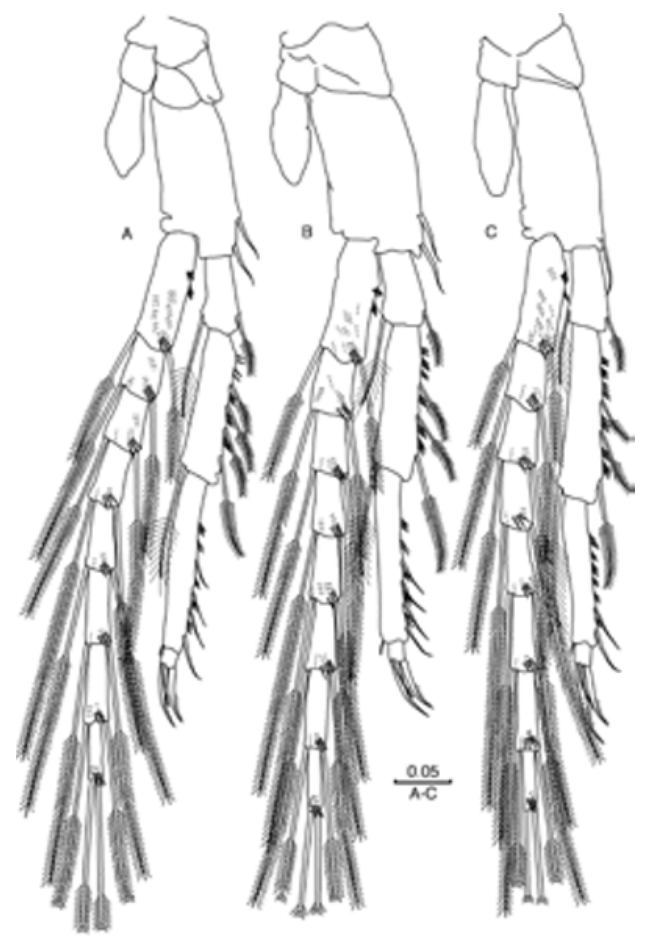

Figure 12. Paraeobathynella siamensis n. sp. Male holotype. A: Thoracopod V; B: Thoracopod VI and C: Thoracopod VII. Scale bar: in $\mathrm{mm}$.

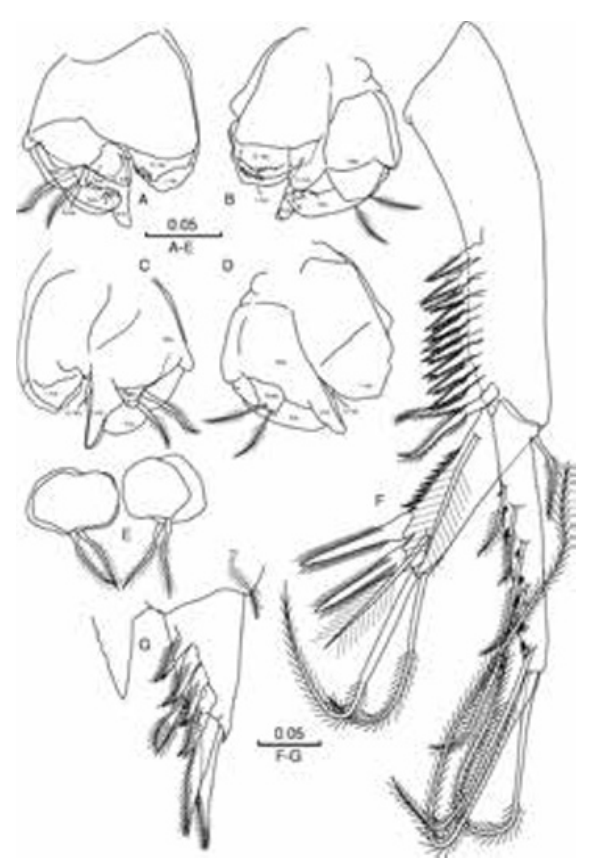

Figure 13. Paraeobathynella siamensis n. sp. Male holotype. A: Thoracopod VIII (lateral internal view); B: Thoracopod VIII (latero-external view); C: Thoracopod VIII; D: Thoracopod VIII; E: Female Thoracopod VIII; F: uropod (lateral view); G: Pleotelson and furca (dorsal view). Scale bar: in $\mathrm{mm}$. 


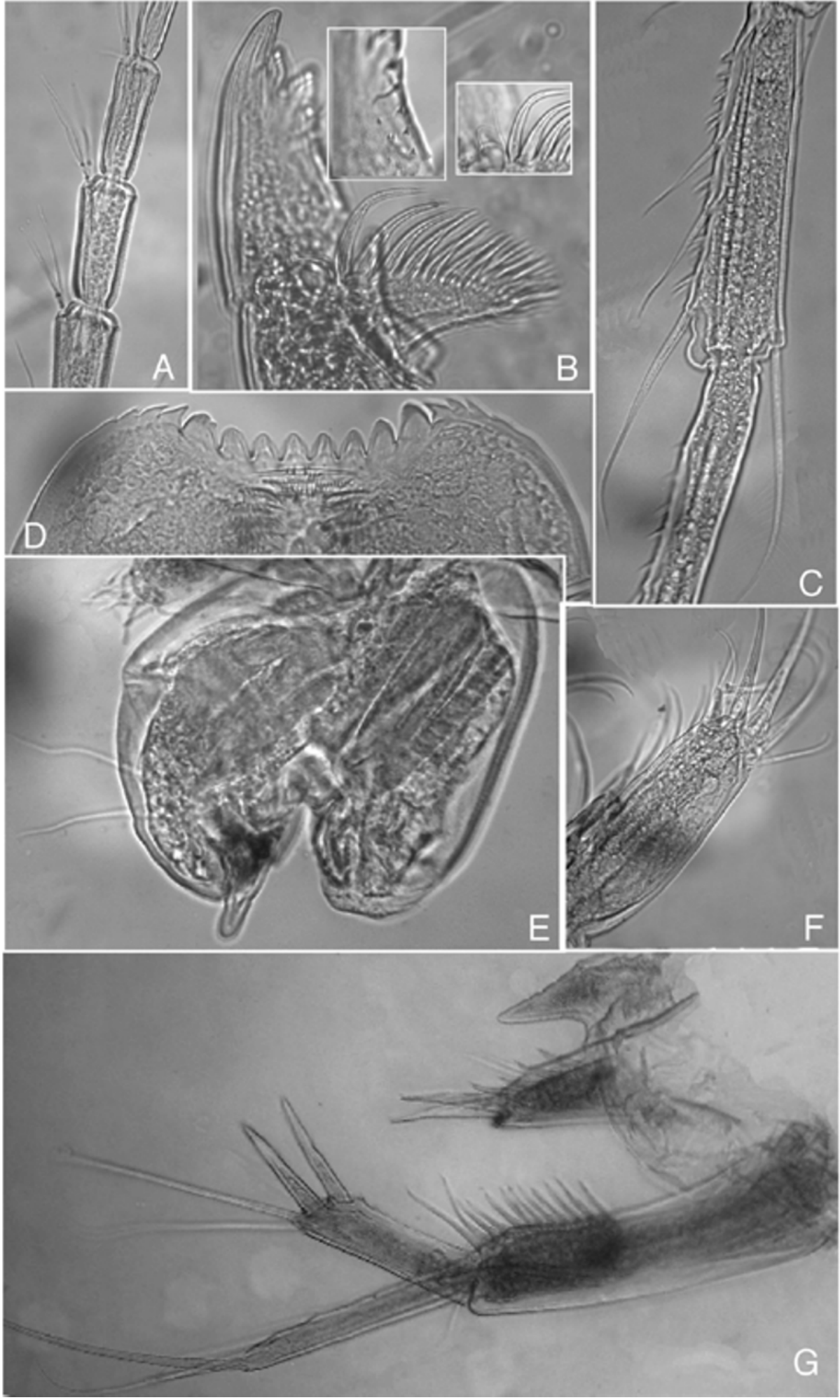

Figure 14. Paraeobathynella siamensis $\mathrm{n}$. $\mathrm{sp}$. Male holotype. A: Antennule, detail of aestethascs; B: Mandible; C: Thoracopod III, detail ofsecond segment of endopod; D: Labrum; E: Thoracopod VIII (lateral internal view); F: Maxilla, detail of distal part; G: Pleotelson, furca and uropod. 
juveniles). The morphological type series contains 13 slides (seven males and seven females; ARTP Collection MNCN20.04/19837-19842 and 1984419850) together with DNA extractions (six whole specimens; DNA types: MNCN/ADN54686-54691) (see Tab. 1 and 2. The description is based on all adult specimens of the type series. All drawings aside the female Th VIII correspond to the male holotype.

Short diagnosis: 9-segmented AI; 7-segmented AII; Md, pars incisiva 8 teeth, pars molaris 15 teeth; MxII, setal formula, 3/3/12/4; basipod Th III-VII, 2 setae; exopod Th I, 4-5 segmented; exopod Th II-VII, 5-9 segmented; absent pleopods; uropod, 10-13 different spines on sympod, 8 setae on exopod, 2 spines and 4 setae on endopod; furca, 6-7 spines; protruded extra large size anal operculum.

\section{Description}

Body: Total length of holotype $2.62 \mathrm{~mm}$. Total length of males $(n=7): 1.70-2.60 \mathrm{~mm}$; females $(n=7)$ : 1.84-2.40 mm. Body elongate (Fig. 9). Head longer than broad.

Antennule (Fig. 10A): 9-segmented, not sexuallydimorphic; length of proximal 4 segments combined similar to distal 5 combined; segment 2 short, half length of first segment, almost square; inner flagelum rectangular; segments 4 and 5 short, similar in length; last 4 segments similar in length, segments 6 and 7 slightly longer than distal 2; setation as in Fig. 10A; segments 6 and 7 with two aesthetascs, segments 8 and 9 with three aesthetascs; aesthetascs on last segment placed subdistally, one longer than rest (Figs 10A; 14A).

Antenna (Fig. 10B): Slightly shorter than first 6 antennulary segments combined, 7-segmented: first 3 segments short; fourth and last 2 segments similar in length; fifth segment slightly longer than $2 / 3$ length of sixth; last segment with 3 simple and one plumose terminal setae; segments 1,2 and 5 naked; setation on other segments as in Fig. 7B. Setal formula: $0 / 0 / 1+0 / 1+1 / 0 / / 2+2 / 4(1)$.

Labrum (Figs 10C; 14D): Concave, with 16 teeth, of which outer 4 at each side smaller than rest; ventral surface with several rows of fine spinules.

Mandible (Figs 10D; 14B): Pars incisiva with 8 well developed teeth, 2 small denticles and 2 proximal seta-like teeth; pars molaris with 14 claws, 12 of which strong and denticulate, 2 more proximal setulose, smaller and joined basally; mandibular palp not exceeding pars incisiva.

Maxillule (Fig. 10E): Proximal endite with 4 unequal claws; distal endite with 7 claws, apical one smooth, rest denticulate; 3 simple setae implanted subdistally on outer margin of endite as figured.

Maxilla (Figs 10F; 14F): 4-segmented; setal formula: $3,4,12,4$.

Thoracopods I-VII (Figs 11; 12; 14C): Well developed, length slightly increasing from Th I to Th III, Th IV-VII similar in size; well developed coxal epipod on Th II-VII, reaching little more than half length of basipod. Basipods all similar in length except in Th I-Th II, which are slightly shorter than rest; all basipods with 2 lateral setae. Exopod of Th I 5-segmented (Fig. 11A), 6-segmented on Th II (Fig. 11B), 7-segmented on Th III and 8-segmented on Th IV-VII (Figs. 11D; 12A-C); exopod of Th I shorter than corresponding endopod, rami similar in length in Th II- III, and exopod longer than endopod in Th IV- VII; all exopodal segments with 2 barbed setae and groups of ctenidia both at base of setae and along segments (see Figs 11; 12). Endopod 4-segmented in all thoracopods, with proximal segment half length of second segment, second and third segments similar in length, both with clusters of strong spinules along outer margin; fourth segment reduced, with 2 strong claws and one simple seta. Setal formula of endopod as: Th I, 4+1/4+1/4+1/3(1); Th II, $2+1 / 4+1 / 5+1 / 3(1)$; Th III, $1+1 / 4+1 / 5+1 / 3(1)$; Th IV $1+1 / 4+1 / 5+1 / 3(1)$; Th V, $1+1 / 4+1 / 4+1 / 3(1)$; Th VI, $1+1 / 3+1 / 4+1 / 3(1)$; Th VII, $1+1 / 3+1 / 2+1 / 3(1)$; outer seta on first and second segments of Th I-VII plumose.

Male Thoracopod VIII (Figs 13A-D; 14E): Large, almost square; basal region massive; inner lobe completely integrated into basal region, barely exceeding distal end of dentate lobe; basipod with one very long distal protuberance on inner edge, like a vertical crest, which exceeds both the end of inner lobe and the exopod; endopod almost square, with 2 long barbed setae distally; exopod large, longer than wide, overhanging both basipod and outer lobe; outer lobe large, trapezoidal, not fused with basipod and exceeding end of outer side of latter; dentate lobe with rounded distal end, with few teeth, overlapped by inner lobe.

Female Thoracopod VIII (Fig. 13E): Large, with smooth cuticle, apple-like in appearance, with 2 long barbed setae distally.

Pleotelson (Fig. 13G;14G): Anal operculum narrow and elongate, triangular, more than $2 / 3$ as long as furcal rami; ventral seta barbed, reaching up to midway of furcal ramus.

First pleopods: Absent. 
Uropod (Figs 13F; 14G): Sympod 4.6 times as long as wide, with 12 barbed spines along distal half of outer margin, 2 distalmost spines about 1/3 longer than rest. Endopod shorter than exopod, with 2 strong barbed spines, 1 strong denticle and 2 unequal plumose setae distally,and with 2 plumose setae along outer margin; many clusters of ctenidia on dorsal face of segment as figured. Exopod with 2 barbed distal setae, one of them very elongate, and 6 barbed setae along outer margin; each seta with group of ctenidia at base.

Furca (Figs 13G; 14G): Rami eachwith 6 barbed spines ( 2 terminal ones much longer and thicker than rest). Dorsal face of rami each with the two setae characteristic of members of the family Parabathynellidae placed at $2 / 3$ of its length; both setae barbed and about half as long as ramus.

Variability. There is variation in the number of spines on the furca (6-7) and the sympod of the uropod (11-13), as well as on the number of segments of AI (8-9) and of exopod of thoracopods (Th I, 4-5; Th II, 5-7; Th III, 6-7; Th IV-VII, 7-9). Furthermore, there is some variation in the setal formula of the endopod of thoracopods: Th I, 4+1/4-5+1/4$5+1 / 3(1)$; Th II, $2-3+1 / 4-5+1 / 5+1 / 3(1)$; Th III, $1+1 / 4-$ $5+1 / 5+1 / 3(1)$; Th IV-V $1+1 / 4+1 / 4-5+1 / 3(1)$; Th VI, $1+1 / 3-4+1 / 4+1 / 3(1)$; Th VII, $1+1 / 3-4+1 / 2-3+1 / 3(1)$. Sometimes the variability occurs in appendages of the same specimen (left and right counterparts).

Etymology. Species name refers to the former name of Thailand, i.e. Siam, where it was discovered for the first time. The epitheton is a noun in the genitive singular masculine.

\section{Paraeobathynella hanjavanitiana Camacho and Watiroyram n. sp. (Figs 15-19)}

http://zoobank.org/urn:lsid:zoobank.org:act: A1003D2E-F2BA-422C-821C-A43704FC72AE

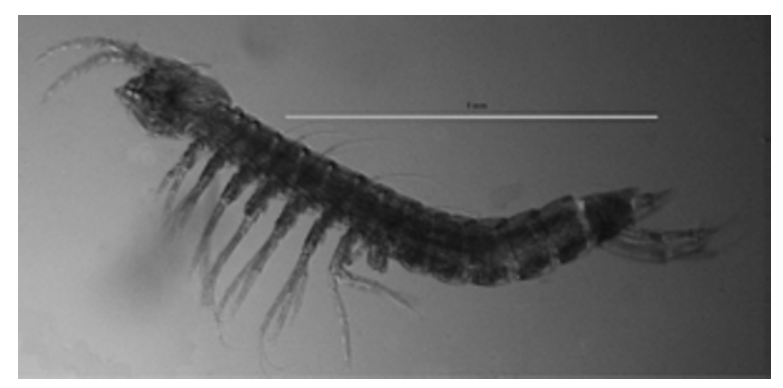

Figure 15. Habitus of Paraeobathynella hanjavanitiana n. sp. Scale bar: in $\mathrm{mm}$.

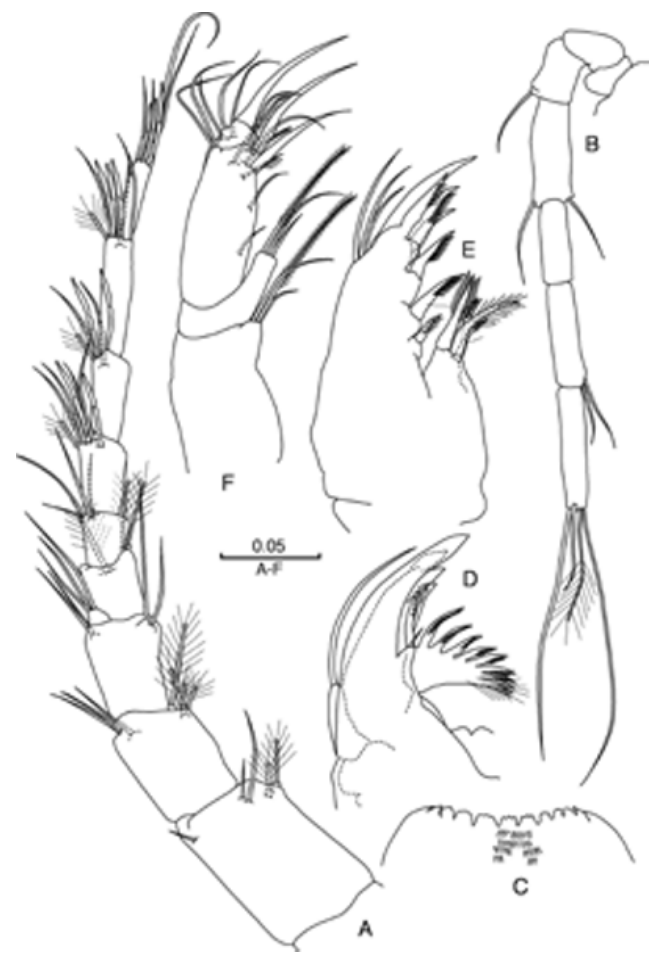

Figure 16. Paraeobathynella hanjavanitiana n. sp. Male holotype. A: Antennule; B: Antenna; C: Labrum; D: Mandible; E: Maxillule; F: Maxilla. Scale bar: in $\mathrm{mm}$.

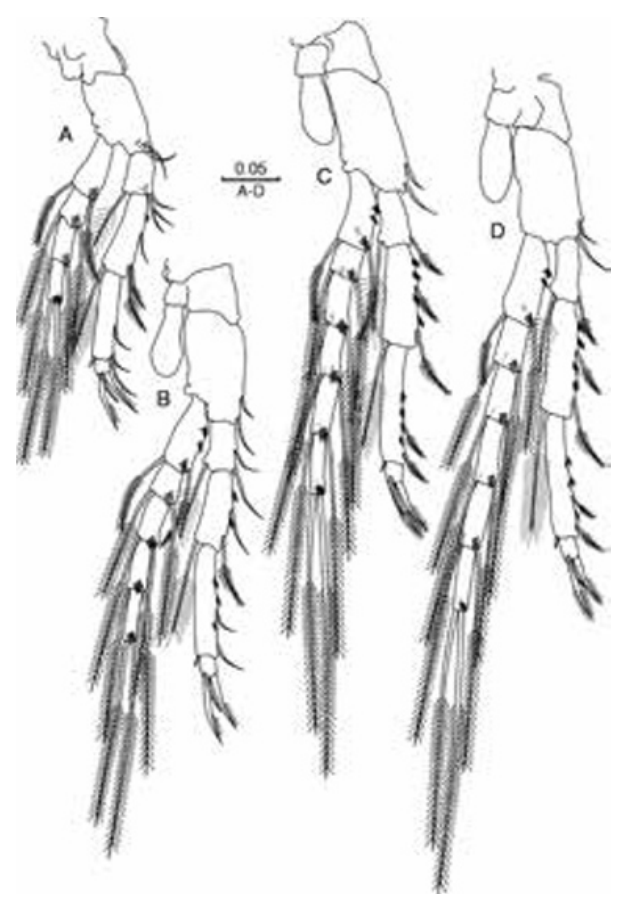

Figure 17. Paraeobathynella hanjavanitiana n. sp. Male holotype. A: Thoracopod I; B: Thoracopod II; C: Thoracopod III; D: Thoracopod IV. Scale bar: in mm. 


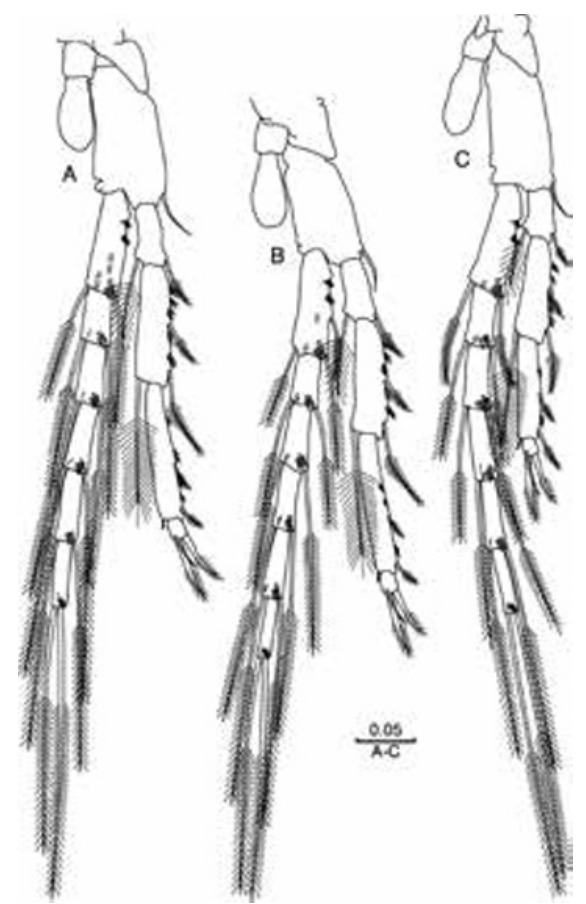

Figure 18. Paraeobathynella hanjavanitiana n. sp. Male holotype. A: Thoracopod V; B: Thoracopod VI; C: Thoracopod VII. Scale bar: in mm.

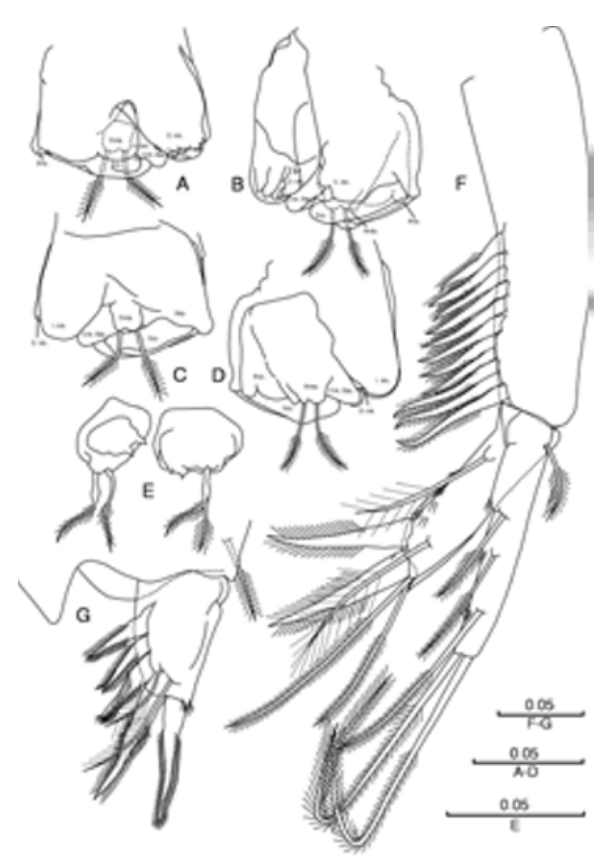

Figure 19. Paraeobathynella hanjavanitiana n. sp. Male holotype. A: Thoracopod VIII (lateral internal view); B: Thoracopod VIII (latero-external view); C: Thoracopod VIII (latero-frontal view); D. Thoracopod VIII (latero-caudal view); F: Female Thoracopod VIII; G: Uropod (lateral view); H: Pleotelson and furca (dorsal view). Scale bar: in mm.
Material examined (Tables 1,2)

Type material: The specimens were collected at Khao Plu Cave, Khao Ro subdistrict, Thung Song district, Nakhon Si Thammarat province, Southern Thailand $\left(09^{\circ} 14^{\prime} 22.00^{\prime \prime} \mathrm{N} 99^{\circ} 48^{\prime} 72.00\right.$ 'E; $56 \mathrm{~m}$ a.s.1.) on 29.10.2015. Holotype male (ARTP Collection MNCN20.04/19855) collected together with 46 specimens (20 males, 19 females and seven juveniles). The morphological type series contains 12 slides (seven males and five females; ARTP Collection MNCN20.04/19851-19854 and 19856-19862) together with DNA extractions from six whole specimens(DNA types MNCN/ADN54692-54697) (see Tabs. 1 and 2). The description is based on all adult specimens of the type series. All drawings correspond to the male holotype except the female Th VIII.

Short diagnosis: 8-9-segmented AI; 7-segmented AII; Md, pars incisiva 8 teeth, pars molaris 10 teeth; MxII, setal formula, 3/3/11/4; basipod Th III-VII, 2 setae; exopod Th I, 4 segmented; exopod Th II-VII, 5-6 segmented; absent pleopods; uropod, 9-12 different spines on sympod, 6 setae on exopod, 2 spines and 4 setae on endopod; furca, 5-7 spines; protruded medium size anal operculum.

\section{Description}

Body: Total length of holotype $1.79 \mathrm{~mm}$. Total length of males ( $n=6)$ : 1.23-1.72 mm; females $(n=6): 1.41-1.66$ mm. Body elongate (Fig. 15). Head longer than broad.

Antennule (Fig. 16A): Not sexually-dimorphic, 9-segmented; length of first 4 segments combined almost similar to last 5 combined; first segment largest, fifth smallest; segment 2 almost square; inner flagelum trapezoidal; third, sixth and seventh segments similar in size, small; segments 6 and 7 with two aesthetascs, segments 8 and 9 with three aesthetascs; aesthetascs on segment 9 subdistal, one of them longer than rest. Setation on segments as figured.

Antenna (Fig. 16B): A little longer than first 6 antennulary segments combined. 7-segmented: first 3 segments short; segments 4,6 and 7 similar in length; segment 5 as long as $2 / 3$ length of fourth segment; terminal segment with 3 simple and one plumose distal setae; segments 1, 2 and 5naked; setation on other segments as figured. Setal formula: $0 / 0 / 1+0 / 1+1 / 0 / 0+2 / 4(1)$.

Labrum (Fig. 16C): Slightly concave, with 12 teeth of which 8 medial multi-cuspidate whereas 2 lateral at each side smaller and unicuspid; ventral surface with several rows of fine spinules.

Mandible (Fig. 16D): Pars incisiva with 6 well 
Table 3. Character variability in Asian genera of the family Parabathynellidae. 1. Allobathynella Morimoto and Miura, $1957 ; 2$. Eobathynella Birstein and Ljovuschkin, 1964; 3. Paraeobathynella Camacho, 2005; 4. Sketinella Camacho, 2005; 5. Sinobathynella Camacho, Trontelj and Zagmajster, 2006; 6. Kampucheabathynella Cho, Kry and Chhenh, 2015. Abbreviations: A =Absent; AI =Antennule; AII = Antenna; C = Cave; dist.endt = distal endite; End = Endopod; Exp = Exopod; Hom = Homonomous; $\mathbf{I n h}=$ Inhomonomous; $\mathbf{m a x}=$ Maximun length in $\mathrm{mm} ; \mathbf{L}=$ Large; $\mathbf{M}=$ Medium-sized; $\mathbf{N}=$ Number of; NPr= Not Pronounced; $\mathbf{P}=$ Present; $\mathbf{P r}=$ Pronounced $\mathbf{R}=$ River bank $\mathbf{S}=$ Small; seg = segmented; sgt = segment $; \mathbf{S y m p}=$ Sympod $; \mathbf{T h}=$ Thoracopod $; \mathbf{T h} \mathrm{I}=$ Thoracopod 1; Th VIII = Thoracopod 8; Urp = Uropod; $\mathbf{W}=$ Well .

\begin{tabular}{|c|c|c|c|c|c|c|}
\hline & 1 & 2 & 3 & 4 & 5 & 6 \\
\hline A I: N sgt & $6-8$ & $6 / 7$ & $7-9$ & 8 & 10 & 10 \\
\hline male antennal organ & A & A & A & A & A & A \\
\hline A II: N sgt & $5-7$ & $5 / 6$ & $6-7$ & 6 & 6 & 7 \\
\hline Mx I: N claws (dist.endt.) & $5-8$ & $4 / 6 / 7$ & 7 & 7 & 7 & 9 \\
\hline Th I: epipod & $\mathrm{A} / \mathrm{P}$ & A & $\mathrm{A}$ & A & $\mathrm{A}$ & A \\
\hline Exp: N sgt & $2-4$ & $1-2$ & $3-5$ & 3 & 7 & 8 \\
\hline Th II: epipod & $\mathrm{A} / \mathrm{P}$ & A & $\mathrm{A} / \mathrm{P}$ & A & A & A \\
\hline Exp: N sgt & $2-6$ & $2-3$ & $4-7$ & 4 & 9 & 9 \\
\hline Th III epipod & $\mathrm{A} / \mathrm{P}$ & $\mathrm{A} / \mathrm{P}$ & $\mathrm{P}$ & $\mathrm{P}$ & $\mathrm{P}$ & $\mathrm{P}$ \\
\hline Exp: $\mathrm{N}$ sgt & $2-7$ & $2-3$ & $5-7$ & 5 & 10 & 10 \\
\hline Th IV-V epipod & $\mathrm{P}$ & $\mathrm{P}$ & $\mathrm{P}$ & $\mathrm{P}$ & $\mathrm{P}$ & $\mathrm{P}$ \\
\hline Exp: N sgt & $2-7$ & $2-4$ & $5-8$ & 5 & 10 & 10 \\
\hline Th VI-VII epipod & $\mathrm{P}$ & $\mathrm{P}$ & $\mathrm{P}$ & $\mathrm{P}$ & $\mathrm{P}$ & $\mathrm{P}$ \\
\hline Exp: N sgt & $2-7$ & $2-4$ & $5-9$ & 5 & 10 & $10-11$ \\
\hline Th VIII male: $\mathrm{N}$ setae end & 2 & 1 & 2 & 2 & 2 & 2 \\
\hline Th VIII female (seg) & 1 & 1 & 1 & - & 1 & 1 \\
\hline setae number & $0-1$ & 0 & 2 & - & 2 & 3 \\
\hline Pleopod seg/seta & $1 \operatorname{seg}$ or $\mathrm{A}$ & A & A & as seta & $\mathrm{A}$ & $\mathrm{A}$ \\
\hline Urp: Symp: spines & $5 / 18$ & $5 / 10$ & $7-13$ & 12 & 20 & 25 \\
\hline type spines & Hom/Inh & Hom/Inh & Hom/Inh & Inh & Hom/Inh & Inh \\
\hline Exp: $\mathrm{N}$ setae & 3-6 & 2-4 & 6-8 & 7 & 8 & 9 \\
\hline End: $\mathrm{N}$ spines & $0 / 2 / 5 / 6$ & $0 / 1 / 3$ & 2 & 2 & $4 / 3$ & 2 \\
\hline $\mathrm{N}$ setae & $2-5$ & $2-4$ & 4 & 4 & 4 & 4 \\
\hline Furca: N spines & 3-8 & $3-5$ & 4-7 & 7 & $9 / 10$ & $7-8$ \\
\hline Anal operculum & $\operatorname{Pr}(\mathrm{S}-\mathrm{L}) / \mathrm{A}$ & $\operatorname{Pr}(\mathrm{S}-\mathrm{M}) / \mathrm{A}$ & $\operatorname{Pr}(\mathrm{S}-\mathrm{XL})$ & $\operatorname{Pr}(\mathrm{M})$ & $\operatorname{Pr}(\mathrm{S})$ & $\operatorname{Pr}(\mathrm{S})$ \\
\hline Length max & 3.2 & 2.3 & 2.6 & 1.9 & 3.7 & 4.7 \\
\hline Habitat & $\mathrm{W} / \mathrm{C}$ & $\mathrm{W} / \mathrm{R}$ & $\mathrm{C}$ & $\mathrm{C}$ & $\mathrm{C}$ & W \\
\hline
\end{tabular}

developed teeth and one small proximal spine-like tooth; pars molaris with 11 claws, of which 8 more proximal strong and denticulate, distal 3 more slender, setulose and joined at base; mandibular palp not exceeding pars incisiva.

Maxillule (Fig. 16E): Proximal endite with 4 unequal claws; distal endite with 7 claws, of wich 2 distalmost smooth, rest with strong spines; 3 subterminal simple setae on outer distal margin of endite as figured.
Maxilla (Fig. 16F): 4-segmented; first and second segments with 3 setae each, setae unequal in length, longest plumose, other 2 simple; third segment elongate, with 11 setae, two of them much stronger than rest; fourth segment with a strong terminal seta and one subterminal and 2 lateral slender setae.

Thoracopods I-VII (Figs 17; 18): Well developed, length slightly increasing from Th I-IV, last four Ths similar in size. Well developed epipod on Th II-VII, reaching more than half length of corresponding 
basipod. All basipods similar in length except that on Th I, which is slightly shorter than rest; 2 lateral setae on basipod of Th I-IV and one on Th V-VII. Exopod 4-segmented on Th I (Fig. 17A), 5-segmented on Th II (Fig. 17B), 6-segmented on Th III-VII; exopod shorter than endopod on Th I-II, similar on Th III-IV, and longer on Th V-VII; all exopodal segments with 2 barbed setae and one cluster of ctenidia at base of each seta. Endopod 4-segmented, first segment similar in all Ths, half length of second segment; third segment longer than second, similar in all Ths; fourth segment reduced, with 2 smooth strong claws of similar length and one simple seta. Setal formula of endopods: Th I, $3+1 / 3+1 / 3+1 / 3(1)$; Th II, $2+1 / 2+1 / 2+1 / 3(1)$; Th IIIVII, $1+1 / 2+1 / 2+1 / 3(1)$; outer seta on first and second segments plumose.

Male Thoracopod VIII (Fig. 19A-D): Large, almost square; basal region massive; inner lobe completely integrated into basal region, barely exceeding distal end of dentate lobe; basipod with one crest-like protuberance distally on inner lateral edge exceeding end of internal lobe. Endopod large, trapezoidal, with 2 long barbed setae. Exopod longer than wide and overhanging both basipod and outer lobe, with 2 distal teeth; rounded outer lobe fused with basipod, exceeding outer side of basipod; dentate lobe overlapped by inner lobe, with large teeth and rounded distal end.

Female Thoracopod VIII (Fig. 19E): Large, rounded, cuticle smooth, with 2 long strong barbed setae distally and 2 teeth at base.

Pleotelson (Fig. 19G): anal operculum triangular, about half as long as furcal rami; ventral seta barbed, reaching up to midway of furcal ramus.

First pleopods: Absent.

Uropod (Fig. 19F): Sympod 4.0 times as long as wide, with 11 barbed spines along distal half of margin, 3 distalmost setae longer than rest; sympod longer than both endopod and exopod. Endopod attaining about 0.75 length of exopod, with 2 strong barbed spines on distal end, 2 unequal barbed setae and one strong denticle distally; 2 plumose setae along outer margin of segment; 3 groups of ctenidia on dorsal face. Exopod with 2 distal barbed setae similar in length, and with 4 shorter barbed setae along outer margin.

Furca (Fig. 19G): Rami rectangular, each with 5 barbed spines, 2 terminal ones slightly longer and thicker than rest. Dorsal side of rami each with the 2 setae characteristic of members of the family Parabathynellidae barbed and unequal in length, longer one reaching tip of terminal spine.
Etymology.The new species is named after Assoc. Prof. Chutima Hanjavanit, supervisor when younger co-author (SW) was a bachelor student. The epitheton is a noun in the genitive singular masculine.

\section{Taxonomic remarks}

The three new species described herein belong to a group of Asian genera characterized by the common display of a large body size (length of specimens close to $2 \mathrm{~mm}$ ) non-sexually dimorphic AI with 7 or more segments, AII with more than 5 segments, and Th IIVII with exopods composed of more than 2 segments (Table 3). This group includes Allobathynella; Eobathynella Birstein and Ljovuschkin, 1964; Kampucheabathynella Cho, Kry and Chhenh, 2015; Paraeobathynella; Sinobathynella Camacho et al., 2006 and Sketinella Camacho, 2005. Paraeobathynella and Sketinella, originally described from Vietnam, are closely related as discussed at the time (Camacho, 2005a). The three new species described herein fit well in Paraeobathynella and display a number of features that separate them from the monotypic Sketinella trontelji Camacho, 2005 (Tables 3; 4). Namely: lack of pleopods (versus pleopod I present but reduced to a single seta in Sketinella); AII 7-segmented; labrum with more than 11 teeth; epipod present on Th II; exopod of Ths 3- to 8-segmented; basipod of some Ths with 2 setae; and male Th VIII with a large exopod and a large crest-like protuberance on basipod. The 6 genera mentioned above are nevertheless very close morphologically and some of their diagnoses overlap in many features. For example, the diagnosis of Allobathynella by Schminke (2011) for could also stand for Paraeobathynella, Eobathynella and Sketinella.

Comparison among the four species of the genus Paraeobathynella (Tables 4 and 5) reveals that 2 of them, P. ratensis $\mathrm{n}$. sp. and P. hanjavanitiana $\mathrm{n}$. sp., are similar in body size and slightly larger than the type species $P$. vietnamensis, whereas they are considerably smaller than $P$. siamensis n. sp. (Table 4). The species with the largest number of segments on AI, P. siamensis n. sp., is also the largest in body size, together with the medium-sized $P$. hanjavanitiana n. sp. Setation in AI varies slightly among species with $P$. siamensis n. sp. displaying the highest number of setae. In all 4 species of the genus Paraeobathynella, the aesthetascs on the terminal segment of AI are positioned subdistally, a feature shared also with Sketinella and most of other Asian genera (Allobathynella, Sinobathynella, 
Table 4. Character variability in species of Sketinella Camacho, 2005 and Paraeobathynella Camacho, 2005. Abbreviations: A = Absent; $\mathbf{A I}=$ Antennule; $\mathbf{A I I}=$ Antenna; dist.endt = distal endite; End = Endopod; Exp = Exopod; Hom = Homonomous; Inh = Inhomonomous; $\mathbf{M}=$ Medium-sized; $\mathbf{N}=$ Number of; $\mathbf{N P r}=$ Not Pronounced $\mathbf{P}=$ Present $; \mathbf{P r}=$ Pronounced; $\mathbf{S}=\mathbf{S m a l l} ; \mathbf{S y m p}=$ Sympod; $\mathbf{T h}=$ Thoracopod; $\mathbf{T h} \mathbf{I}=$ Thoracopod 1; Th VIII = Thoracopod 8; $\mathbf{X L}=$ Extra large.

\begin{tabular}{|c|c|c|c|c|c|}
\hline & S. trontelji & P. vietnamensis & $P$. ratensis $\mathrm{n} . \mathrm{sp}$. & P. siamensis $\mathrm{n} . \mathrm{sp}$. & $\begin{array}{l}\text { P. hanjavanitiana } \\
\text { n.sp. }\end{array}$ \\
\hline A I: N segments & 8 & 7 & 8 & 9 & $8-9$ \\
\hline male antennal organ & A & A & A & A & A \\
\hline A II: N segments & 6 & 6 & 7 & 7 & 7 \\
\hline setal formula & $0 / 0+1 / 1+1 / 0 / 1+1 / 4$ & $0 / 0+1 / 1+1 / 0 / 2+0 / 4$ & $0 / 0 / 0+1 / 1+1 / 0 / 2+0 / 4$ & $0 / 0 / 0+1 / 1+1 / 0 / 2+2 / 4$ & $0 / 0 / 0+1 / 1+1 / 0 / 2+0 / 4$ \\
\hline Labrum & $2+8+2$ & $3+8+3$ & $2+4+1+4+2$ & $4+8+4$ & $\begin{array}{l}3+8 \text { (three } \\
\text { cuspidated)+3 }\end{array}$ \\
\hline Md: pars incisiva ( $\mathrm{N}$ teeth) & 6 & 5 & 5 & 8 & 8 \\
\hline pars molaris ( $\mathrm{N}$ claws) & $8(5+3)$ & $10(8+2)$ & $7(5+2)$ & $15(13+2)$ & $10(8+2)$ \\
\hline Mx I: N claws (dwist.endt) & 7 & 7 & 7 & 7 & 7 \\
\hline Mx II: setal formula & $2 / 3 / 11 / 5$ & $2 / 3 / 12 / 3$ & $3 / 3 / 11 / 4$ & $3 / 3 / 12 / 4$ & $3 / 3 / 11 / 4$ \\
\hline Th I: basipod (N setae) & 1 & 2 & 2 & 2 & 2 \\
\hline Epipod & $\mathrm{A}$ & A & A & A & A \\
\hline Exp.: $\mathrm{N}$ segments & 3 & 3 & $3-4$ & $4-5$ & 4 \\
\hline Th II: basipod (N setae) & 1 & 1 & 2 & 2 & 2 \\
\hline Epipod & A & $\mathrm{A}$ & $\mathrm{P}$ & $\mathrm{P}$ & $\mathrm{P}$ \\
\hline Exp: N segments & 4 & 4 & $4-5$ & $5-7$ & 5 \\
\hline Th III: basipod (N setae) & 1 & 1 & 1 & 2 & 2 \\
\hline Exp: N segments & 5 & 5 & 5 & $6-7$ & 6 \\
\hline Th IV: basipod (N setae) & 1 & 1 & 1 & 2 & 2 \\
\hline Exp: N segments & 5 & 5 & 5 & $7-8$ & 6 \\
\hline Th V: basipod (N setae) & 1 & 1 & 1 & 2 & 1 \\
\hline Exp: N segments & 5 & 5 & 5 & $7-8$ & 6 \\
\hline Th VI-VII: basipod (N setae) & 1 & 1 & 1 & 2 & 1 \\
\hline Exp: N segments & 5 & 5 & $5-6$ & $7-9$ & 6 \\
\hline Th VIII male: $N$ setae end & 2 & 2 & 2 & 2 & 2 \\
\hline Th VIII female: N segments & --- & 1 & 1 & 1 & 1 \\
\hline $\mathrm{N}$ setae & --- & 1 & 2 & 2 & 2 \\
\hline Pleopod & $\mathrm{P}$ as seta & A & A & A & A \\
\hline Uropod: Symp: N spines & $10+2$ & 7 & $7-9$ & $8-11+2$ & $6-9+3$ \\
\hline type spines & Inh & Inh & Hom & Inh & Inh \\
\hline Exp: N setae & 7 & 6 & 6 & 8 & 6 \\
\hline End: $\mathrm{N}$ spines & 2 & 2 & 2 & 2 & 2 \\
\hline $\mathrm{N}$ setae & $2+2$ & $2+2$ & $2+2$ & $2+2$ & $2+2$ \\
\hline Exp/End & Exp $>$ End & Exp=End & Exp=End & Exp $>$ End & Exp $>$ End \\
\hline Sympod/Exp & Sympod $>$ Exop & Sympod $>$ Exp & Sympod $>$ Exp & Sympod $>$ Exp & Sympod $>$ Exp \\
\hline Furca: N. spines & 7 & 5 & $4-5$ & $6-7$ & $5-7$ \\
\hline setae & 2 similar & 2 similar & 2 different & 2 similar & 2 different \\
\hline Anal operculum & $\operatorname{Pr}(\mathrm{M})$ & $\operatorname{Pr}(\mathrm{M})$ & $\operatorname{Pr}(\mathrm{S})$ & $\operatorname{Pr}(\mathrm{XL})$ & $\operatorname{Pr}(\mathrm{M})$ \\
\hline Pleotelson: ventral seta & Short, half furca & Medium, as furca & Short, half furca & Short, less half furca & Medium, as furca \\
\hline Length (maximun) (mm) & 1.9 & 1.7 & 1.8 & 2.6 & 1.8 \\
\hline Habitat & Cave & Cave & Cave & Cave & Cave \\
\hline
\end{tabular}


Table 5. Character variability in thoracopods of Paraeobathynella Camacho, 2005. Abbreviations: End = Endopod; Exp = Exopod; $\mathbf{N}$ $=$ Number of; $\mathbf{T h}=$ Thoracopod; $\mathbf{T h} \mathbf{I}=$ Thoracopod 1 ; $\mathbf{T h}$ VII $=$ Thoracopod 7.

\begin{tabular}{|c|c|c|c|c|}
\hline & P. vietnamensis & P. ratensis $\mathrm{n} . \mathrm{sp}$. & P. siamensis n.sp. & P. hanjavanitiana n.sp. \\
\hline Th I: Exopod/endopod & Exp $<$ End & Exp $<$ End & Exp $<$ End & Exp $<$ End \\
\hline Endopod: setal formula & $3+1 / 3+1 / 3+1 / 3(1)$ & $3+1 / 3+1 / 2+1 / 3(1)$ & $4+1 / 4-5+1 / 4-5+1 / 3(1)$ & $3+1 / 3+1 / 3+1 / 3(1)$ \\
\hline Exp.: $\mathrm{N}$ segments & 3 & $3-4$ & $4-5$ & 4 \\
\hline Th II: Exopod/endopod & Exp $<$ End & Exp $<$ End & Exp=End & Exp $<$ End \\
\hline Endopod: setal formula & $1+1 / 3+1 / 2+1 / 3(1)$ & $1+1 / 2+1 / 3+1 / 3(1)$ & $2-3+1 / 3-5+1 / 3-5+1 / 3(1)$ & $2+1 / 2+1 / 2+1 / 3(1)$ \\
\hline Exp.: N segments & 4 & $4-5$ & $5-7$ & 5 \\
\hline Th III: Exopod/endopod & Exp=End & Exp=End & Exp=End & Exp=End \\
\hline Endopod: setal formula & $1+1 / 3+1 / 2+1 / 3(1)$ & $1+1 / 3+1 / 2+1 / 3(1)$ & $1-2+1 / 4-5+1 / 3-5+1 / 3(1)$ & $1+1 / 2+1 / 2+1 / 3(1)$ \\
\hline Exp.: $\mathrm{N}$ segments & 5 & 5 & $6-7$ & 6 \\
\hline Th IV: Exopod/endopod & Exp $>$ End & Exp=End & Exp $>$ End & Exp=End \\
\hline Endopod: setal formula & $1+1 / 2+1 / 2+1 / 3(1)$ & $1+1 / 2+1 / 2+1 / 3(1)$ & $1+1 / 3-5+1 / 2-5+1 / 3(1)$ & $1+1 / 2+1 / 2+1 / 3(1)$ \\
\hline Exp.: N segments & 5 & 5 & $7-8$ & 6 \\
\hline Th V: Exopod/endopod & Exp>End & Exp=End & Exp>End & Exp $>$ End \\
\hline Endopod: setal formula & $1+1 / 2+1 / 2+1 / 3(1)$ & $1+1 / 2+1 / 2+1 / 3(1)$ & $1+1 / 3-5+1 / 2-5+1 / 3(1)$ & $1+1 / 2+1 / 2+1 / 3(1)$ \\
\hline Exp.: N segments & 5 & 5 & $7-8$ & 6 \\
\hline Th VI: Exopod/endopod & Exp $>$ End & Exp=End & Exp>End & Exp>End \\
\hline Endopod: setal formula & $1+1 / 2+1 / 2+1 / 3(1)$ & $1+1 / 2+1 / 2+1 / 3(1)$ & $1+1 / 3-5+1 / 3-4+1 / 3(1)$ & $1+1 / 2+1 / 2+1 / 3(1)$ \\
\hline Exp.: $\mathrm{N}$ segments & 5 & $5-6$ & $7-9$ & 6 \\
\hline Th VII: Exopod/endopod & Exp $>$ End & Exp $>$ End & Exp>End & Exp $>$ End \\
\hline Endopod: setal formula & $1+1 / 2+1 / 2+1 / 3(1)$ & $1+1 / 2+1 / 2+1 / 3(1)$ & $1+1 / 2-4+1 / 2-4+1 / 3(1)$ & $1+1 / 2+1 / 2+1 / 3(1)$ \\
\hline Exp.: $\mathrm{N}$ segments & 5 & $5-6$ & $7-9$ & 6 \\
\hline Length (maximun) (mm) & 1.7 & 1.8 & 2.6 & 1.8 \\
\hline
\end{tabular}

Siambathynella Camacho, Watiroyram and Brancelj, 2011, Hangangbathynella Park and Cho, 2013, Kampucheabathynella, Arisubathynella Park and Eun, 2012, Mekongbathynella Nam and Cho, 2014, and Eobathynella).

Whereas AII is 7-segmented in the three new species, it is only 6-segmented in the type species $P$. vietnamensis. However, setation is similar in the 3 smaller species, while the largest species $P$. siamensis n. sp. displayss 2 additional setae on the sixth segment. There is no correlation between body size and number of teeth and/or spines present on the Md: P. siamensis n. sp. and $P$. hanjavanitiana n. sp. each have 8 teeth in the pars incisiva while the other two smaller species have 5; in the pars molaris the larger species has more spines than the rest, but the one with the least, $P$. ratensis $\mathrm{n}$. sp., is not the smallest ( $P$. vietnamensis is smaller). The three new species display an epipod on Th II while the type species does not, as $S$. trontelji. The highest number of segments on thoracopodal exopods occurs in the largest species (between 4 and 9), whereas the lowest occurs in the smaller species (between 3 and 5).
Whereas $P$. vietnamensis displays only one seta on the basipod in all thoracopods, the three new species bear 2 setae on the basipod of Th I-II. Furthermore, $P$. hanjavanitiana displays 2 setae also on the basipod of Th III-IV, whereas P. siamensis on Th II-VI. Male Th VIII is more rectangular in P. hanjavanitiana $\mathrm{n}$. sp. and more square in the rest of species (basipod height variable). There are differences in size of the basipod crest (it is longer and straighter in P. siamensis n. sp.); the size and shape of the outer lobe and length and curvature of the exopod, which is larger and less curved in P. siamensis n. sp. (see Figs 8A-D; 13A-B; 14E; 19A-D).

The female Th VIII has only 1 seta in P. vietnamensis versus 2 setae in the rest of species; furthermore there are 2 small teeth in all species except $P$. siamensis $\mathrm{n}$. sp. which lacks teeth.

The largest number of spines (13) on the sympod of uropods is found in P. siamensis n. sp.P. hanjavanitiana n. sp. has up to 12 spines while the similar sized $P$. ratensis $\mathrm{n}$. sp. displays 8 spines. Spines in P. ratensis n. sp. are all of the same size, whereas in P. siamensis n. sp. and P. hanjavanitiana n. sp., the 2 and 3 distal- 
most spines, respectively, are longer than the rest. In $P$. vietnamensis the 2 distal-most spines are the smallest. P. siamensis $\mathrm{n}$. sp. has 8 setae on the exopod of uropod, whereas the other three species of the genus display 6 ,. The furcal ramus has between 5 and 7 spines and is between triangular to square in three new species and in P. vietnamensis (see Table 4). The two ventral setae of the pleotelson characteristic for the family Parabathynellidae are similar in length in $P$. vietnamensis and $P$. siamensis $\mathrm{n}$. sp., but are unequal in the other two species. The anal operculum is very pronounced in $P$. siamensis n. sp., small in P. ratensis n. sp. and medium-sized in $P$. vietnamensis and $P$. hanjavanitiana $\mathrm{n} . \mathrm{sp}$.

\section{Appendix 2}

Distribution of Asian species of the family Parabathynellidae

The current distribution of the 74 Asian species within the family Parabathynellidae covers only 11 out of the 48 countries from four regions of Asia: East Asia (Japan, South Korea, China), Southeast Asia (Malaysia, Indonesia, Vietnam, Thailand and Cambodia), Central Asia (Kirghizistan and Uzbekhistan) and South Asia (India) (Fig. 20). Species belong to 17 genera whose distribution is uneven (see Camacho, 2005, 2006; Camacho et al., 2011; Ranga Reddy, 2006; Ranga Reddy and Schminke, 2005; Ranga Reddy and Totakura, 2010). Seven genera are monospecific, while the genus Allobathynella is one of the most diverse genera of the family, with 23 species and it is equal to the cosmopolitan genus Hexabathynella (with 23 species) and Iberobathynella (22 species restricted to the Iberian Peninsula and the Balearic Islands only). Recently there have been found in India species of genera known so far only from other continents: Africa (Habrobathynella Schminke, 1973) and Australia and South America (Chilibathynella Noodt, 1963; Atopobathynella Schminke, 1973) (Ranga Reddy, 2002, 2004, 2006; Ranga Reddy and Schminke, 2005, 2009; Ranga Reddy et al., 2008; Ranga Reddy et al., 2014; Bandari et al., 2016). Also, in the last two decades new genera have been found in Asian countries where no Syncarida were known, such as Vietnam (Camacho, 2005), China (Camacho et al., 2006), Thailand (Camacho et al., 2011) or Cambodia (Nam and Cho, 2014; Cho et al., 2015) whereas in Japan and Korea new species of Nipponbathynella Schminke, 1973 (Morimoto, 2002;
Cho et al., 2008; Cho et al., 2009; Park and Cho, 2015) and Allobathynella Morimoto and Miura, 1957 (Park and Cho, 2008, 2016) have been found as well as new genera Arisubathynella Park and Eun, 2012 and Hangangbathynella Park and Cho, 2013.

Some genera like Allobathynella, Nipponbathynella or Eobathynella that have been considered to be restricted only to Japan and/or South Korea have been found recently also in Kirghizistan and Uzbekhistan. The genus Paraeobathynella that was previously known only from Vietnam now contains three new species, described in this paper. It is the second genus known from Thailand, and Siambathynella is the only other genus known from this country (Fig. 20). There are still many unexplored areas in Asia, and around the world, that undoubtedly harbour many new genera and species.

The distribution of the 17 Asian genera and the 74 species (and subspecies) known is as follows (TL $=$ Type Locality; Ha = Habitat):

Allobathynella Morimoto and Miura, 1957

Synonym: Parabathynella Chappuis, 1926 (partim) and Eobathynella Birstein and Ljovuschkin, 1964 (partim).

1. A. bangokensis Park and Cho, 2016. TL: BangokRi, Seo-My-eon, Hongcheon-Gun, Ganwon-Do, South Korea. Ha: interstitial.

2. A. buronensis Park and Cho, 2016. TL: Wonju-Si Buron-Myeon Heungho-Ri, Ganwon-Do, South Korea. Ha: interstitial.

3. A. carinata (Uéno, 1952). TL: Hachioji City, western suburbs of Tokyo, Japan. Ha: well.

4. A. cheongdoensis Park and Cho, 2016. TL: Dongchang stream (Riv- er Nakdong tributary), Geumgok-Ri, Maejeon-Myeon, Cheongdo-Gun, Kyungsangbuk-Do, South Korea. Ha: interstitial.

5. A. coreana Morimoto, 1970. TL: Yongdam-gul Cave, Byeollidong, Hadong-myeon, Yeongweolgun, Kangweon-do, South Korea. Ha: caves. Other localities: Kwangcheon-seon-gul Cave, Kwangcheon-ri, Daehwa-myeon, Pyeongchanggun, Kangwen-do and Wangreung-ri, Ka'eunmueon, Mun'gyeong-gun, Kyeongsang-puk do, South Korea.

6. A. donggangensis Park and Cho, 2016. TL: gravel bank of small stream (Eochun) of Donggang, Jeongseon-Eup (town), Jeongseon- Gun (county), Kangwon-Do (province), South Korea. Ha: interstitial. 
7. A. gangneungensis Park and Cho, 2016. TL: Imgok-Ri, Gang- dong-Myeon, Gangneung-Si, Kangwon-Do, South Korea. Ha: interstitial.

8. A. gigantea gigantea (Morimoto, 1959). TL: San, northeastern coast of Tokunoshima Island, central Ryu-Kyu, Japan. Ha: wells. Other localities: Yakugachi, Sumiyô-son, southern part of AmamiOshima Island, central Ryu-Kyu, Japan.

9. A. gigantea pluto (Morimoto, 1963). TL: Shimohanda, Dainan-chô, Ôita prefecture, Kyushu, Japan. Ha: wells. Other localities: Myyazaki City and Tsuma, Saito City, Miyazaki
Kyushu, Japan.

10. A. hongcheonensis Park and Cho, 2016. TL: Bangok-Ri, Seo-My-eon, Hongcheon-Gun, Ganwon-Do, South Korea. Ha: interstitial.

11. A imjinensis Park and Cho, 2016. TL: Imjin river, Yeoncheon-Gun Baekhak-Myeon Nogok-Ri, Geonggi-Do, South Korea. Ha: interstitial.

12. A. japonica Morimoto and Miura, 1957. TL: Wadayama, Japan Sea, Hyogo, South of Honshu, Japan. Ha: well. Other localities: wells in Taishimachi and Aioi City, Hyôgo Prefecture, South of Honshu, Japan.

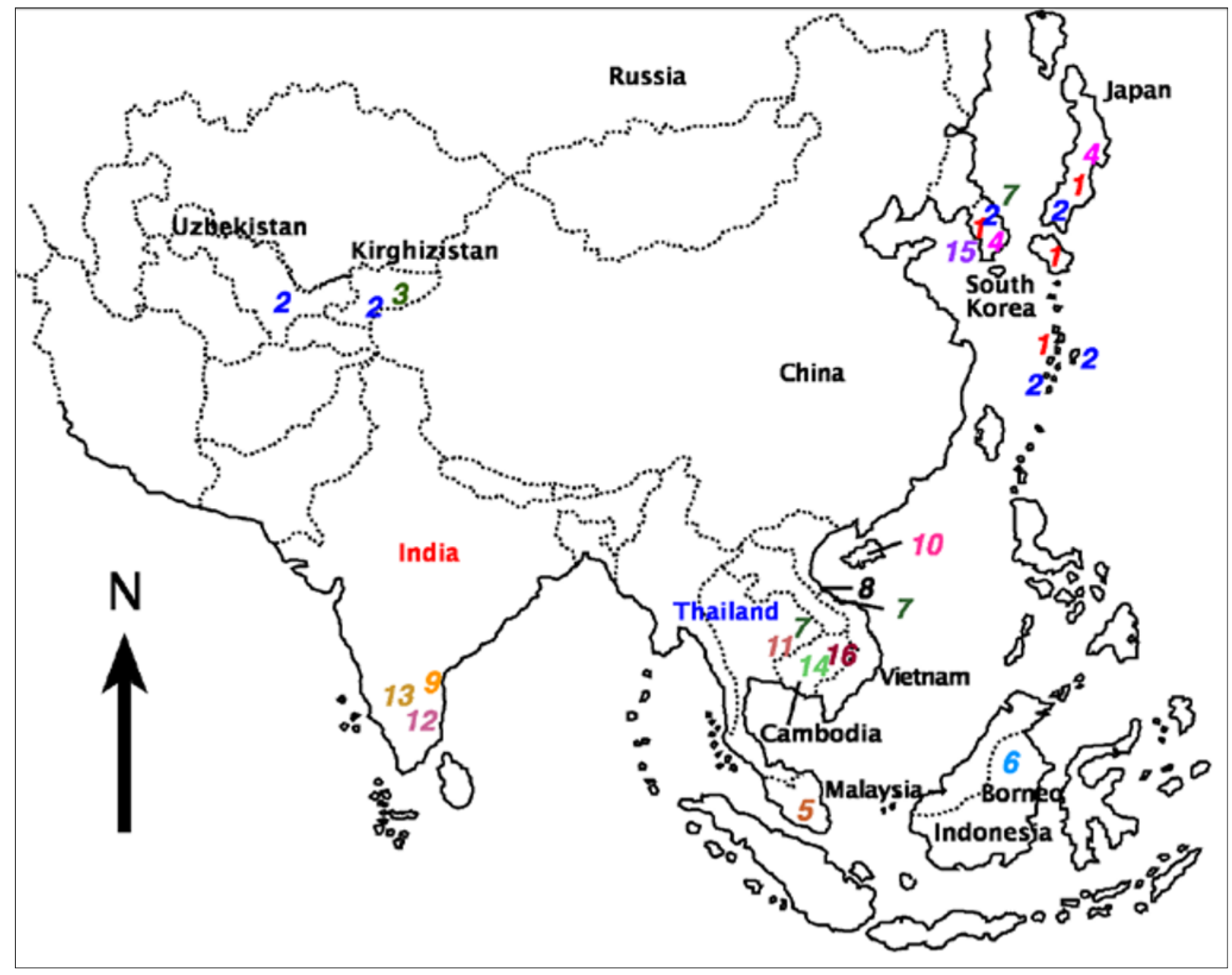

Figure 20. Distribution map of the genera of Parabathynellidae present in Asia. 1. Allobathynella Morimoto and Miura, $1957 ; 2$. Eobathynella (Birstein and Ljovuschkin, 1964); 3. Issykkulibathynella Serban, 1994; 4. Nipponbathynella Schminke, 1973 ; 5. Batubathynella (Sars, 1929); 6. Sabahbathynella Schminke, 1988; 7. Paraeobathynella Camacho, 2005; 8. Sketinella Camacho, 2005; 9. Habrobathynella Schminke, 1973; 10. Sinobathynella Camacho, Trontelj and Zagmajster, 2006; 11. Siambathynella Camacho, Watiroyram and Brancelj, 2011; 12. Chilibathynella Noodt, 1963; 13. Atopobathynella Schminke, 1973; 14. Mekongbathynella Nam and Cho, 2014; 15. Arisubathynella Park and Eun, 2012; 16. Kampucheabathynella Cho, Kry and Chhenh, 2015; 17. Hangangbathynella Park and Cho, 2013. 
13. A. kuma (Uéno, 1956). TL: Hinagu, Kumamoto, west coast of Kyushu, Japan. Ha: well.

14. A. maseongensis Park and Cho, 2016. TL: Shinheon-Ri, Maseong-Myeon, Munkyeong-Si, Kyungsangbuk-Do, South Korea. Ha: interstitial.

15. A. mirabilis Uéno, 1961. TL: Takéfu, Tsuruga, Fukui Prefecture, Honshu, coast of Japan Sea, Japan. Ha: well.

16. A. munmakensis Park and Cho, 2016. TL: Anchang-Ri, Munmak-Eup, Wonju-Si, GanwonDo, South Korea. Ha: interstitial.

17. A. munsui Park and Cho, 2016. TL: JoongpyeongRi, Pacheon-Myeon, Cheongsoung-Gun, Kyungsangbuk-Do, South Korea. Ha: interstitial.

18. A. okcheonensis Park and Cho, 2016. TL: Okcheon-Gun Iweon-Myeon, ChungcheogbukDo, South Korea. Ha: interstitial.

19. A. shinjongieei Park and Cho, 2008. TL: Geochang, Kyungsangnamdo, South Korea. Ha: well.

20. A. wonjuensis Park and Cho, 2016. TL: Wonju-Si Jijeong-Myeon Wolho-dong, Gangwondo, South Korea. Ha: interstitial.

21. A. yaye (Uéno, 1956). Yaye, Hiroshima, Yoshida, south of Honshu, coast of Japan Sea, Japan. Ha: well.

22. A.yecheonensis Park and Cho, 2016.TL: YonggungMyeon, Yecheon-Gun, Gyeongsangbuk-Do, South Korea. Ha: interstitial.

23. A. yeongjuensis Park and Cho, 2016. TL: YeongjuSi Mun-jeong-Myeon, Kyungsangbuk-Do, South Korea. Ha: interstitial.

\section{Arisubathynella Park and Eun, 2012}

24. A. cheongmiensis Park and Eun, 2012. TL: sandbank of Cheongmi stream (tributary of the Han River), Jumdongmyon Dori, Kyeonggi-Do, Yeoju-Gun, South-Korea. Ha: interstitial.

25. A. hongcheonensis Park and Cho, 2015. TL: Bangok-Ri, Seo-Myeon, Hongcheon-Gun, Ganwon-Do, South-Korea. Ha: interstitial.

26. A. imjinensis Park and Cho, 2015. TL: Nogok-Ri, Baekhak-Myeon, Yeoncheon-Gun, Geonggi-Do, South-Korea. Ha: interstitial.

\section{Atopobathynella Schminke, 1973}

Synonym: Parabathynella Chappuis, 1926 (partim).

27. A. indica Bandari, Saik and Ranga Reddy, 2017.

TL: Borewell at Araveetikota, Giddalur town, Andhra Pradesh State, South India. Ha: well.

28. A. inopinata Bandari, Saik and Ranga Reddy, 2017. TL: Borewell at Kunchanapalli village,
Guntur district, Andhra Pradesh State, South India. Ha: well.

29. A. nelloreensis Bandari, Saik and Ranga Reddy, 2017. TL: Borewell at Krishnapatnam, Nellore town, Andhra Pradesh State, South India. Ha: well.

30. A.operculata Ranga Reddy, Drewes and Schminke, 2008. TL: Godavari River, Rajahmundry, South India. Ha: interstitial.

31. A. paraoperculata Ranga Reddy and Totakura, 2015. TL: River Krishna, Chamarti village, Guntur district, Andhra Pradesh State, South India. Ha: interstitial. Southeastern India

Batubathynella Schminke, 1973

Synonym: Parabathynella Chappuis, 1926 (partim), Allobathynella Morimoto and Miura, 1957 (partim) and Eobathynella Birstein and Ljovuschkin, 1964 (partim).

32. B. malaya (Sars, 1929). Batu caves, near to Kuala Lumpur, Selangor State. Malaysia. Ha: cave.

Chilibathynella Noodt, 1963

33. C. kotumsarensis Ranga Reddy, 2006. TL: Kotumsar Cave, near Jagdalpur, Bastar District, Chhattisgarh State, India. Ha: cave.

Eobathynella Birstein and Ljovuschkin, 1964

Synonym: Parabathynella Chappuis, 1926 (partim) and Allobathynella Morimoto and Miura, 1957 (partim).

34. E. gracillima (Uéno, 1956). TL: Yoshida, Takadagun, Hiroshima. Honshu, Japan. Ha: wells. Other localities: Yaye, west to Yoshida, Honshu; Nazé City, Amami- Oshima Island, Japan.

35. E. gracillima insularis (Morimoto, 1959). TL: Genka-gawa river, Genka and Nago, Nago-shi, Okinawa-honto Island, Japan. Ha: interstitial and well.

36. E. matuta (Morimoto, 1970). TL: No'eum-ri, Keunnam-myeon, Uljin-gun, Kyeongsang-pukdo, west coast of South Korea. Ha: well.

37. E. mesasiatica Birstein and Ljovuschkin, 1964. TL: Plavikova mountain near Khaidarkan, Frunzenskii region, Osh, Kirghizistan (former republic of USSR). Ha: cave.

38. E. minima (Jankowskaja, 1972). Bukhchasai River, Kyzyl-Kum (desert), Nuraty in Bukhara, Republic of Uzbekistan (former republic of USSR). Ha: interstitial.

39. E. yeojuensis Schminke, 2011. TL: Jumdongmyon 
Dori, Yeoju county, Kyunggi-Do, South Korea. Ha: unknown.

\section{Habrobathynella Schminke, 1973}

Synonym: Parabathynella Chappuis, 1926 (partim).

40. H. adishankara Bandari, Shaik and Ranga Reddy, 2016. TL: River Periyar at Kalady willage, Kerala State, South India. Ha: interstitial.

41. H. ajraoi Totakura and Ranga Reddy 2014. TL: Govindupalem village, Elamanchili town in Visakhapatnam district, Andhra Pradesh state, South India. Ha: well.

42. H. borraensis Ranga Reddy, Shaik and Totakura, 2014. TL: Borra Caves near Visakhapatnam, Ananthagiri hills of the Araku valley in the Visakhapatnam district, Andhra Pradesh state, South India. Ha: cave.

43. H. indica Ranga Reddy and Schminke, 2005. TL: Krishna River, Vijayawada near Kanaka Durga Varadhi, South India. Ha: interstitial.

44. H. nagarjunai Ranga Reddy, 2002. TL: Nagarjuna University, near Guntur town, Andhra Pradesh, South India. Ha: well.

45. H. krishna Ranga Reddy and Totakura, 2010. TL: Krishna River, Ramannapeta, Guntur district, Andhra Pradesh, South India. Ha: interstitial. Other localities: Krishna River, Madipadu, Guntur district, Andhra Pradesh, South India.

46. H.muvattupuzha Bandari, Shaik and Ranga Reddy, 2016. TL: River Muvattupuzha at Muvattupuzha town, Kerala State, South India. Ha: interstitial.

47. H. parakrishna Totakura and Ranga Reddy 2014. TL: bore in riparian zone of the River Krishna at Mopidevi village, Machilipatnam, Krishna district, Andhra Pradesh state, South India. Ha: interstitial.

48. H. pseudoindica Totakura and Ranga Reddy, 2014. TL: Krishna River, Chamarti village, Guntur district, Andhra Pradesh state, South India. Ha: interstitial.

49. H. plenituda Ranga Reddy and Schminke, 2009. TL: Godavari River, Rajahmundry, South India. Ha: interstitial.

50. H. savitri Ranga Reddy and Totakura, 2010. TL: Godavari River, Sundarapalli, East Godavari District, Andhra Pradesh, South India. Ha: interstitial. Other localities: Godavari River, Dhawaleswaram and Kapileswarapuram, East Godavari District, Andhra Pradesh, S India.

51. H. schminkei Ranga Reddy, 2004. TL: Pennar River, near Cuddapah, South India. Ha: interstitial.
52. H. vaitarini Ranga Reddy and Totakura, 2010. TL: Krishna River, Madipadu, Guntur district, Andhra Pradesh, South India. Ha: interstitial. Other localities: Krishna River, Pulichintala and Challagariga, Guntur district, Andhra Pradesh, South India.

53. H. vidua Ranga Reddy and Totakura, 2010. TL: Tadepalli, near Vijayawada, Krishna District, Andhra Pradesh, South India. Ha: wells. Other localities: Kunchanapalli, Krishna District, Andhra Pradesh, South India.

Hangangbathynella Park and Cho, 2013

54. H. eunokae Park and Cho, 2013. TL: YongmunMyeon Samsung-Ri, Yangpyeong-Gun, Kyeonggi-Do, South-Korea. Ha: well.

55. H. taechooni Park and Cho, 2013. TL: Cheongmi stream (River Han tributary), Jumdong-Myon DoRi, Yeoju-Gun, Kyeonggi-Do, South-Korea. Ha: interstitial.

Issykkulibathynella Serban, 1994

Synonym: Parabathynella Chappuis, 1926 (partim) and Eobathynella Birstein and Ljovuschkin, 1964 (partim).

56. I. tianschanica (Jankowskaja, 1964). TL: Issykkul Lake in Tian Shan Mountains, near Biological Station of the Academie of Sciences of Kyrgyzstan, Tian-Chan North, Kyrgyzstan (former republic of USSR). Ha: well.

Kampucheabathynella Cho, Kry and Chhenh, 2015

57. K. khaeiptouka Cho, Kry and Chhenh 2015. TL: sandbank of Mekong River, Tou Vihea village, Tbong Kmom District, Kampong Cham Province, Cambodia. Ha: interstitial.

Mekongbathynella Nam and Cho, 2014

58. M. kryi Nam and Cho, 2014. TL: Sesan River, Mekong River tributary, Kvang village, Vien Sai district, Siem Pang Province, Cambodia. Ha: interstitial.

59. M. sesanensis Nam and Cho, 2014. TL: Sesan River, Mekong River tributary, Kvang village, Vien Sai district, Siem Pang Province, Cambodia. Ha: interstitial.

Nipponbathynella Schminke, 1973

Synonym: Parabathynella Chappuis, 1926 (partim). 60. N. donggangensis Park and Cho, 2015. TL: Donggang stream, a tributary of The Han-River, 
Jeongseon-Eup (town), Jeongseon-Gun (county), Kangwon-Do (province), South Korea. Ha: interstitial.

61. N. leesookyungae Park and Cho, 2015. TL: stream in Gaeshin Village Yeongam-Eup (town), Yeongam-Gun (county), Jeollanam-Do (province), South Korea. Ha: interstitial.

62. N. miurai (Uéno, 1952). TL: Himeji City, Hyôgo Prefecture, south of Honshu, Japan. Ha: wells. Other localities: Aioi City, Hyôgo Prefecture, south of Honshu, Japan.

63. N. pectina Cho, Hwang and Nam, 2008. TL: Gunbuk-Myeon, Okchun-Gun, ChungchungnamDo, South Korea. Ha: well.

64. N. shigaensis Park and Cho, 2015. TL: sand bank of Mankyeonggang, Gueok-Ri (village), YongjinMyeon (town), Wanju-Gun (county), JeollabukDo (province), South Korea. Ha: interstitial.

65. N. uozumii Morimoto, 2002. TL: Kaifu-gawa River, Yoshida, Kaifu-chô, Tokushima Prefecture, southeastern coast of Shikoku, Japan. Ha: interstitial.

66. N. wanjuensis Park and Cho, 2015. TL: sand bank of Mankyeonggang, Gueok-Ri (village), YongjinMyeon (town), Wanju-Gun (county), JeollabukDo (province), South Korea. Ha: interstitial.

\section{Paraeobathynella Camacho, 2005}

67. P. hanjavanitiana n. sp. Camacho and Watiroyram 2018. TL: Khao Plu cave, Khao Ro Subdistrict, Thung Song District, Nakhon Si Thammarat Province, Southern Thailand. Ha: cave.

68. $P$. ratensis n. sp. Camacho and Watiroyram 2018. TL: Rat cave, Kapang Subdistrict, Thung
Song District, Nakhon Si Thammarat Province, Southern Thailand. Ha: cave.

69. P. siamensis n. sp. Camacho and Watiroyram 2018. TL: Khao Krot cave, Kuanthong Subdistrict, Khanom District, Nakhon Si Thammarat Province, Southern Thailand. Ha: cave.

70. P. vietnamensis Camacho, 2005. TL: Hang Trinh $\mathrm{Nu}$, Bo Hon Island, Vinh Ha Long, Vietnam. Ha: caves. Other localities: Trung Trang Cave, and Ang Vem Cave, Cat Ba Island, W of Vinh Ha Long, Vietnam.

Sabahbathynella Schminke, 1988

71. S. wongi Schminke, 1988. TL: Sungai Masalong, between Keningau and Tenon, Sabah, Borneo Island, Indonesia. Ha: interstitial.

Siambathynella Camacho, Watiroyram and Brancelj, 2011

72. S. laorsriae Camacho. TL: Tham Yai Nam Nao cave, Nam Nao National Park, Phetchabun, Thailand. Ha: cave.

Sinobathynella Camacho, Trontelj and Zagmajster, 2006

73. S. decamera Camacho, Trontelj and Zagmajster, 2006. "Si Haizi Dong" cave (Four Children's Cave), some $300 \mathrm{~m}$ south from Qiantian village, Changjiang County, Hainan Island, China. Ha: cave.

Sketinella Camacho, 2005

74. S. trontelji Camacho, 2005. TL: Rom Island, Vinh Ha Long, E part, Vietnam. Ha: cave. 